Nat. Hazards Earth Syst. Sci., 20, 1335-1351, 2020

https://doi.org/10.5194/nhess-20-1335-2020

(C) Author(s) 2020. This work is distributed under

the Creative Commons Attribution 4.0 License.

\title{
An 18-year climatology of derechos in Germany
}

\author{
Christoph P. Gatzen ${ }^{1}$, Andreas H. Fink ${ }^{2}$, David M. Schultz ${ }^{3,4}$, and Joaquim G. Pinto ${ }^{2}$ \\ ${ }^{1}$ Institut für Meteorologie, Freie Universität Berlin, Berlin, Germany \\ ${ }^{2}$ Institute of Meteorology and Climate Research, Department Troposphere Research, Karlsruhe Institute \\ of Technology, Karlsruhe, Germany \\ ${ }^{3}$ Centre for Crisis Studies and Mitigation, University of Manchester, Manchester, UK \\ ${ }^{4}$ Centre for Atmospheric Science, Department of Earth and Environmental Sciences, \\ University of Manchester, Manchester, UK
}

Correspondence: Christoph P. Gatzen (gatzen@met.fu-berlin.de)

Received: 18 July 2019 - Discussion started: 4 September 2019

Revised: 7 March 2020 - Accepted: 17 March 2020 - Published: 19 May 2020

\begin{abstract}
Derechos are high-impact convective wind events that can cause fatalities and widespread losses. In this study, 40 derechos affecting Germany between 1997 and 2014 are analyzed to estimate the derecho risk. Similar to the United States, Germany is affected by two derecho types. The first, called warm-season-type derechos, form in strong southwesterly $500 \mathrm{hPa}$ flow downstream of western European troughs and account for 22 of the 40 derechos. They have a peak occurrence in June and July. Warm-season-type derechos frequently start in the afternoon and move either eastward along the Alpine forelands or northeastward across southern central Germany. Associated proximity soundings indicate strong 0-6 and $0-3 \mathrm{~km}$ vertical wind shear and a median of mixed-layer convective available potential energy (mixed-layer CAPE) around $500 \mathrm{~J} \mathrm{~kg}^{-1}$. The second derecho type, the cold-season-type derecho, forms in strong northwesterly $500 \mathrm{hPa}$ flow, frequently in association with midtropospheric potential vorticity (PV) intrusions, and accounts for 18 of the 40 derechos. They are associated with a secondary peak from December to February. Cold-season-type derechos start over or close to the North Sea and primarily affect northern and central Germany; their start time is not strongly related to the peak of diurnal heating. Proximity soundings indicate high-shear-low-CAPE environments. A total of 15 warm-season-type and 9 cold-season-type derechos had wind gusts reaching $33 \mathrm{~m} \mathrm{~s}^{-1}$ in at least three locations. Although warm-season derechos are more frequent, the path length of cold-season-type derechos is on average 1.4 times longer. Thus, these two types of German derechos are likely to have similar impacts.
\end{abstract}

\section{Introduction}

Convective wind events can produce high losses and fatalities in Germany. One example is the Pentecost storm in 2014 (Mathias et al., 2017), with six fatalities in the region of Düsseldorf in western Germany and a particularly high impact on the railway network. Trains were stopped due to blocked tracks, and trees were blown down and hit overhead power lines, severing connections (Die Welt, 2014). Other examples are the convective windstorm that killed eight in Berlin and Brandenburg on 10 July 2002 (Gatzen, 2004) and a derecho in Poland on 11 August 2017 that caused six fatalities (Taszarek et al., 2019). The high number of casualties is caused by the sudden unexpected occurrence of severe convective storms due to their rapid development (Doswell, 2001), and there are indications that people caught outdoors are not well prepared. Open-air events are at particular risk, as demonstrated by incidents such as that on 6 July 2001 near Strasbourg, France, when trees fell on tents where visitors took cover, killing 12 (European Severe Weather Database (ESWD), CNN, 2001; Dotzek et al., 2009), and at the Pukkelpop open-air festival in Hasselt, Belgium, when estimated wind gusts of $47 \mathrm{~m} \mathrm{~s}^{-1}$ during the 18 August 2011 storm caused five fatalities due to the collapse of tents and parts of the stage (BBC, 2011). A common characteristic of such events is that they travel over large distances of several hundred kilometers, which greatly increases their potential impact due to the large area affected.

Data from the European Severe Storms Laboratory (ESSL) can be used to determine the impact of large-scale convective 
wind events. In 2017, there were 131 fatalities and 783 injuries due to severe weather (including severe winds, heavy rain, tornadoes, and large hail, Groenemeijer et al., 2017). Of these, 41 fatalities and 456 injuries were caused by the most significant 12 large-scale convective windstorms (Groenemeijer et al., 2017). The high potential for fatalities and substantial economic losses due to widespread high-impact weather, in combination with their rapid development, make these convective windstorms among the most challenging forecast situations for weather services and their forecasters.

Similar convective windstorms are known in the United States, where the most intense are called "derechos" (following Hinrichs, 1888; Johns and Hirt, 1987). To classify derechos based on severe wind gust reports and radar reflectivity data, Johns and Hirt (1987) had the following requirements.

- Deep moist convection is associated with concentrated wind occurrence over a path that extends over at least $400 \mathrm{~km}$ along the major length axis. Wind gusts must exceed $26 \mathrm{~m} \mathrm{~s}^{-1}$ as indicated by measurements and/or damage reports.

- Associated wind gusts can be related to the same event so that a chronological progression of singular wind swaths or a series of wind swaths is indicated.

- There must be at least three reports of wind gusts of at least $33 \mathrm{~m} \mathrm{~s}^{-1}$ (and/or related wind damage) separated by $64 \mathrm{~km}$ or more within the area of severe wind gusts.

- All wind reports have to occur within $3 \mathrm{~h}$ of the other wind reports of the same derecho event.

For the United States, Ashley and Mote (2005) estimate that the derecho hazard potential can be as high as that from tropical storms and tornadoes, except for the highestimpact tornadoes and hurricanes. Up to four derechos in 3 years can be expected for $200 \mathrm{~km} \times 200 \mathrm{~km}$ grid boxes in the most affected region southwest of the Great Lakes (Coniglio and Stensrud, 2004). Derechos form in association with mesoscale convective systems that develop bow echoes on plan-view radar displays (Fujita, 1978). Bow echoes indicate strong flow from the rear to the front of a convective system, a so-called rear-inflow jet (e.g., Smull and Houze, 1987; Przybylinski, 1995). The development of rear-inflow jets is fostered by persistent convection initiation along the gust front of a convective system (Mahoney et al., 2009). Studies on the ambient conditions of convective storms have shown that a combination of high convective available potential energy (CAPE) and strong vertical wind shear is one environment that can support this upscale growth (e.g., Rotunno et al., 1988; Corfidi, 2003; Klimowski et al., 2003). In particular, a combination of strong shear and high CAPE can occur during May to July in the United States when derechos commonly occur (Ashley and Mote, 2005). The environment may become so favorable (e.g., during heat waves) that derechos may occur in clusters of several events called "derecho families" during the same large-scale flow situation (Bentley and Sparks, 2003; Ashley et al., 2004). However, derechos can also develop when instability is weak (Johns, 1993; Burke and Schultz, 2004). Instead of high shear and high CAPE, these derechos form in situations with high shear and low CAPE (Sherburn and Parker, 2014), called highshear-low-CAPE environments (e.g., Evans, 2010; King and Parker, 2014).

In contrast to the United States, the term derecho is still not commonly used in Europe, although several events have been classified as such in past decades (Gatzen, 2004; Punkka et al., 2006; López, 2007; Gatzen et al., 2011; Pistotnik et al., 2011; Púčik et al., 2011; Simon et al., 2011; Hamid, 2012; Celiński-Mysław and Matuszko, 2014; Toll et al., 2015; Gospodinov et al., 2015; Mathias et al., 2019; Taszarek et al., 2019). Four of these derechos affected large portions of Germany (Gatzen, 2004; Gatzen et al., 2011; Pistotnik et al., 2011; Mathias et al., 2019). Before 2004, German convective windstorms were not classified as derechos, but there are indications of potential derechos in the previous literature (e.g., Köppen, 1882, 1896; Faust, 1948; Kurz, 1993; Haase-Straub et al., 1997; Kaltenböck, 2004). The low number of classified events does not allow for a risk estimate of derechos in Germany because their characteristics (e.g., the spatiotemporal distribution, typical environmental conditions, and largescale flow patterns) are not known.

Based on the case studies listed above, European derechos possess some similar characteristics to derechos in the United States. For example, they can be divided into warm-seasontype derechos and cold-season-type derechos. The majority of European derecho case studies can be attributed to the warm-season-type derecho. These are frequently associated with rather high CAPE (Púčik et al., 2011; Hamid, 2012; Celiński-Mysław and Matuszko, 2014; Taszarek et al., 2019) compared to the environments of the majority of severe convective wind events (Púčik et al., 2015). Five case studies of the warm-season-type derechos also mention strong vertical wind shear (Gatzen, 2004; Púčik et al., 2011; Hamid, 2012; Celiński-Mysław and Matuszko, 2014; Taszarek et al., 2019). Publications with radar images describe sustained convection initiation along or ahead of a gust front (Gatzen, 2004; Celiński-Mysław and Matuszko, 2014), bow echoes (Gatzen, 2004; Púčik et al., 2011; Hamid, 2012; Celiński-Mysław and Matuszko, 2014; Taszarek et al., 2019), and rear-inflow jets (Gatzen, 2004; Taszarek et al., 2019). Finally, the large-scale flow was frequently from the southwest (e.g., Gatzen, 2004).

Next to the warm-season-type derechos described above, three case studies refer to cold-season-type derechos (Gatzen et al., 2011; Pistotnik et al., 2011; Mathias et al., 2019). In contrast to the examples of German warm-season-type derechos, German cold-season-type derechos form within northwesterly large-scale flow (Gatzen et al., 2011; Pistotnik et al., 2011; Mathias et al., 2019). In particular, Pistotnik et al. (2011) describe a mid-troposphere potential vortic- 
ity (PV) intrusion in one of the cold-season-type derechos. Cold-season-type derechos form along narrow cold-frontal rainbands in an environment similar to the high-shear-lowCAPE situations described for the United States (e.g., Burke and Schultz, 2004; van den Broeke et al., 2005). Classification of cold-season-type derechos can be difficult because strong synoptic-scale winds frequently overlap with convective gusts (e.g., van den Broeke et al., 2005).

Given that only a few European derechos have been analyzed, it is not clear if the described characteristics are typical for German derechos and thus can be useful in operational forecasting. The purpose of this study is to contribute to European convective storms research and present a derecho climatology for Germany. Creating accurate derecho climatologies is laborious due to manual identification, and this study goes beyond the climatology of warm-season wind gusts presented in Gatzen (2013). Our work investigates how often derechos occur across Germany, how intense they are, and which parts of the country are most affected. Another main research question is to determine the differences between derechos that occur in the warm and cold seasons, specifically differences in the large-scale flow patterns and the local thermodynamic environment as given by observational data such as those from radiosonde ascents. The benefit of using this analysis to support operational weather services in potential derecho situations is assessed. Moreover, results are compared to the derecho climatology of the United States, for which more information is available.

Section 2 introduces the data we used and explains the methods used to identify and analyze derechos in Germany. Section 3 presents our results and interpretation of the German derecho climatology and compares it with the derecho climatology of the United States. This section also provides aid to forecasters to support them in identifying potential derecho situations. Finally, Sect. 4 provides the conclusions and an outlook to future work.

\section{Data and methods}

For the derecho classification, we used maximum wind gusts together with radar data using the wetter4 visualization tool of MeteoGroup. Maximum wind gusts are the highest $3 \mathrm{~s}$ averaged wind speed measurements within an hour, taken from the German Weather Service (DWD) surface station network. Additionally, 10 min maximum wind gust measurements were obtained from the Meteomedia/MeteoGroup network. Wind measurement sites increased from 260 to more than 1000 sites between 1997 and 2011. This corresponds to a density between 0.7 and nearly 3 measurement points per $1000 \mathrm{~km}^{2}$ across Germany (approximately $360000 \mathrm{~km}^{2}$ ), with an average station spacing between 10 and $20 \mathrm{~km}$. Beyond the borders of Germany, internationally distributed SYNOP and other data, such as data from buoys and ships, sometimes allowed for following derecho tracks farther into neighboring countries and across the North Sea. Because of a lack of a consistent mosaic of German radar data for this study over the duration of the climatology, two different datasets were required when manually examining processed radar data for derecho identification. Before 1 January 2009, radar data were available in $15 \mathrm{~min}$ intervals, showing the bottom clutter-free value that is found in the column above if it is found below $6 \mathrm{~km}$. These data were interpolated on a Cartesian grid with a horizontal grid spacing of $2 \mathrm{~km}$, a vertical grid spacing of $1 \mathrm{~km}$, time intervals of $15 \mathrm{~min}$, and seven intensity thresholds to produce a radar mosaic over Germany (Schreiber, 1998). On and after 1 January 2009, we used a mosaic of the lowest elevation radar reflectivity at each location available at MeteoGroup. These data were interpolated onto a grid over Germany with cell sizes of $1 \mathrm{~km} \times 1^{\circ}$ azimuth angle, time intervals of $5 \mathrm{~min}$, and intensity classes in 2 dBZ steps (DWD, 1997).

To identify potential derechos, DWD surface wind measurements have been analyzed with respect to concentrated occurrence of severe wind gusts. Following Evans and Doswell (2001), we used a threshold of $25 \mathrm{~m} \mathrm{~s}^{-1}$ to define a severe wind gust as opposed to $26 \mathrm{~m} \mathrm{~s}^{-1}$ as proposed by Johns and Hirt (1987). When more than five stations reported a daily maximum wind gust of $25 \mathrm{~m} \mathrm{~s}^{-1}$ or more, this date was chosen for further analysis. Given the average station spacing of $20 \mathrm{~km}$ or less, we expect a high detection rate of potential derechos using this criterion. However, derechos that start or end close to the borders of Germany may affect fewer than five stations. We expect a decreasing detection rate close to the German borders for this reason. In the months from October to March, when high winds frequently occur with extratropical cyclones, it was more effective to identify potential derechos first based on radar displays, choosing only those dates that indicated the presence of mesoscale convective systems or narrow cold-frontal rainbands (NCFRs). Convective systems were identified on radar displays by high reflectivity and large reflectivity gradients that typically form linear structures, such as bowing line segments. NCFRs identified for cold seasons from 1998/99 to 2008/09 in Gatzen (2011) were completed with events back to 1997 and until 2014 using subjective analysis following Gatzen (2011). A NCFR had to exceed $100 \mathrm{~km}$ in length at one time during its lifetime; its width should be small compared to their length axis (i.e., typically about one to four pixels on the radar composite image, which corresponds to 2-8 km). An aspect ratio was not used. NCFRs with a lifetime less than $1 \mathrm{~h}$ were excluded from the analysis. Bands of precipitation that were likely not related to cold fronts (e.g., convective gust fronts) were also excluded. For dates with more than five severe wind gust measurements (April to September) or indications of NCFRs (October to March), hourly maximum wind gusts of the networks from DWD and Meteomedia/MeteoGroup were analyzed together with planview radar images. Only severe wind gusts were considered 
that could be followed chronologically with the associated mesoscale convective system or NCFR.

In some of the events, severe wind gusts occurred in the environment before the mesoscale convective system or NCFR approached. This happened, for example, when isolated thunderstorms produced wind gusts in the pre-derecho area or when severe non-convective winds occurred ahead of the NCFR. Due to the comparatively large time intervals between available wind gust measurements (i.e., 10 or $60 \mathrm{~min}$ ), some of these wind gusts could not be clearly assigned to the derecho. As a first approximation, we assumed the wind gust intensity to be nearly constant ahead of the convective gust front. When a measurement site reported severe winds prior to the approach of the convective system, it was only used for the derecho classification when it recorded a further increase in the maximum wind gust of at least $3 \mathrm{~m} \mathrm{~s}^{-1}$ during the passage of the convective system or NCFR. The passage of the convective system or NCFR was analyzed using a radar display, as well as observations at the SYNOP station, such as wind direction, temperature, or dew point temperature. This increase in wind speed is about $10 \%$ or roughly one increment on the Beaufort scale and is used to exclude reports with almost constant severe wind gusts ahead of the derecho and no further increase in speed with the derecho passage. This method is also used to estimate the contribution of convection to wind gusts assigned to a derecho, although it is sometimes not possible to clearly distinguish between the contributions of non-convective and convective processes, as discussed in van den Broeke et al. (2005). Based on the resulting subset of severe wind reports, an event was classified as a derecho when there was a concentrated area that could be followed for at least $400 \mathrm{~km}$ along the center line of the associated linear radar structure. All wind measurements had to occur within a distance of less than $167 \mathrm{~km}$ from the other wind measurements. Also, no gaps of more than $2 \mathrm{~h}$ between successive wind reports were allowed, ensuring concentrated severe wind occurrence within the derecho path. This procedure is similar to that introduced by Evans and Doswell (2001).

This study differs from previous derecho climatologies because we included overwater stations such as measurements from buoys, ships, and oil rigs. The threshold of $25 \mathrm{~m} \mathrm{~s}^{-1}$ might be more easily surpassed at open-water stations because the effect of friction on the wind speed is weaker over water compared to land. Wind measurements on oil rigs and ships are not taken at $10 \mathrm{~m}$ but at heights up to $100 \mathrm{~m}$ above the sea level. This difference in wind measurements might lead to a higher rating of a wind event when it moves across open water compared to the land. Furthermore, the density of wind measurements affects the detection rate of derechos. Derechos can be followed across the North Sea where the measurement density is high enough, across the southern North Sea in particular. Across the central and northern North Sea, there are fewer wind measurements, and it was more difficult to follow derecho tracks farther out than $100 \mathrm{~km}$ away from the German coast. For this reason, derecho paths across the North Sea may be shorter and/or less reliable compared to derecho paths over land.

Finally, we used lightning data to follow derecho events into areas where radar data were not available, for example over eastern Europe. We used data from the Arrival Time Difference (ATD) system operated by the Met Office (Lee, 1986) available at wetterzentrale.de (2016) until the year 2000 and from the Siemens Blids lightning network (Siemens, 2019) for events after the year 2000. We decided to expand a derecho path into regions where lighting data allowed a chronological detection of the associated convective system together with the severe wind gust occurrence.

We took the first and the last gust measurements of a derecho to define its location and time of start and dissipation, respectively. The derecho duration was defined as the corresponding time difference. The path length of derechos was calculated by the direct distance between the first and the last wind measurements close to the derecho center line. Following Coniglio and Stensrud (2004), we distinguished between high-end-, moderate-, and low-end-intensity derechos. If a derecho met the requirements set by Johns and Hirt (1987) and included three or more wind measurements of at least $38 \mathrm{~m} \mathrm{~s}^{-1}$, with two of them occurring during the mature phase of the convective system, then it was classified a highend-intensity event. If it met the requirements of Johns and Hirt (1987), i.e., that at least three wind reports of $33 \mathrm{~m} \mathrm{~s}^{-1}$ or greater that are separated by $64 \mathrm{~km}$ or more occur within the derecho path, then the event was classified as moderate intensity. The remaining events were classified as low-endintensity events. Wind damage was not used to classify the derecho intensity. To allow for a comparison of the derecho density to that of the United States, we calculated the spatial derecho density of moderate- and high-end-intensity events for grid boxes of $200 \mathrm{~km} \times 200 \mathrm{~km}$ similar to Coniglio and Stensrud (2004), counting every derecho that at least partly affected a box and computed the spatiotemporal density by dividing the number of derechos per box by the number of analyzed years.

We analyzed the large-scale flow in derecho situations indicated by the $500 \mathrm{hPa}$ geopotential height charts following Evans and Doswell (2001), Burke and Schultz (2004), and Coniglio and Stensrud (2004). Similar patterns in $500 \mathrm{hPa}$ geopotential field were grouped together using the agglomerative hierarchical clustering of the scipy.cluster python package (Berkhin, 2006; Müllner, 2011). Base fields for the clustering were the NCEP/NCAR Reanalysis 2 (available at 00:00, 06:00, 12:00, and 18:00 UTC ${ }^{1}$; Kalnay et al., 1996) $500 \mathrm{hPa}$ geopotential height fields. We used the closest analysis time before the start time of the derecho and normalized the fields with respect to their minimum and maximum

\footnotetext{
${ }^{1}$ Central European time (CET) is UTC +1 in the cold season, and central European summer time (CEST) is UTC +2 in the warm season when daylight savings time is in effect.
} 
geopotential heights in the region of interest. The clustering was done in a latitude-longitude box between $20^{\circ} \mathrm{W}-20^{\circ} \mathrm{E}$ and $40-60^{\circ} \mathrm{N}$. The distance between two normalized geopotential height fields is calculated as the sum of the Gaussian distance between the single grid points. Clusters were joined agglomeratively (bottom-up) by calculating the average distance between clusters. We used $500 \mathrm{hPa}$ to analyze synopticscale situations to compare the clusters with results from the United States (Coniglio et al., 2004). Because PV intrusions have been observed in association with cold-season derechos (e.g., Pistotnik et al., 2011), we also analyzed fields of PV on the $320 \mathrm{~K}$ isentropic surface. As the horizontal resolution of the NCEP/NCAR reanalysis $\left(2.5^{\circ} \times 2.5^{\circ}\right)$ data is low, we used archived GFS (horizontal resolution up to $0.25^{\circ} \times 0.25^{\circ}$ in recent years) charts from wetter3.de (http: //www1.wetter3.de/Archiv/, last access: 31 May 2019), concentrating on PV intrusions, as indicated by sharp PV gradients and large PV values of more than 1.5 PV units (PVU; $1 \mathrm{PVU}=10^{-6} \mathrm{~K} \mathrm{~kg}^{-1} \mathrm{~m}^{2} \mathrm{~s}^{-1}$ ); PV was only available for years after 1998 .

To study thermodynamic environments in which derechos in Germany form, we used proximity soundings determined from criteria used by Evans and Doswell (2001): soundings had to be taken within $150 \mathrm{~km}$ and $2 \mathrm{~h}$ of the derecho path. We used these criteria to allow for a larger number of proximity soundings, although small-scale changes of the environment may have been missed that could be significant to the development of convective storms (e.g., Brooks et al., 1994; Potvin et al., 2010; Apsley et al., 2016). Specifically, Markowski et al. (1998) found mesoscale to stormscale changes of the low-level vertical wind shear near supercells, and Potvin et al. (2010) found that the best distance for proximity soundings from tornadoes is in the range of 40$80 \mathrm{~km}$ and less than $2 \mathrm{~h}$. Moreover, Apsley et al. (2016) analyzed a simulation of a NCFR that showed a narrow zone of CAPE in a narrow strip just ahead of the rainband that would be not indicated by soundings taken more than $100 \mathrm{~km}$ away. For this reason, proximity soundings will be interpreted with care.

Every proximity sounding had to be launched ahead of the convective system or NCFR. To ensure that soundings were released ahead of the derecho gust front, we took the release time that is given in the raw data available at University of Wyoming sounding data archive (http://weather.uwyo. edu/upperair/sounding.html, last access: 15 March 2019) and analyzed the derecho position as indicated by radar data and ground observations, such as wind direction and temperature at the release time. Parameters such as mixedlayer CAPE were taken from the University of Wyoming sounding data archive (http://weather.uwyo.edu/upperair/ sounding.html, last access: 15 March 2019). Here, parameters are based on the lifting curve of the lowest $500 \mathrm{~m}$ mixed-layer parcel using the virtual-temperature correction of Doswell and Rasmussen (1994). Additionally, we computed $0-1 \mathrm{~km}$ vertical wind shear as the magnitude of the vector difference between the wind at $1 \mathrm{~km}$ altitude above ground level and the wind closest to the ground that is always referenced to the $10 \mathrm{~m}$ (or surface) wind regardless of the exact measurement height. Similarly, we computed the 03 and $0-6 \mathrm{~km}$ vertical wind shear using the magnitude of the vector difference between the winds at 3 and $6 \mathrm{~km}$ altitude above ground level and the surface. We linearly interpolated the wind vectors at 1,3 , and $6 \mathrm{~km}$ based on the closest wind measurements near the corresponding heights.

\section{Results}

Between 1997 and 2014, 40 derechos at least partly affected Germany (Table 1). This is more than two derechos every year on average, with a range from zero derechos in 1998 and 2012 to four derechos in 2003. In the following paragraphs, we present the characteristics of German derechos.

\subsection{Derecho occurrence across Germany}

The regional derecho frequency was analyzed based on the areas of each path. Some parts of Germany are much more affected than others. In general, the derecho density increases from the lowlands in the north to the higher terrain in the south, with the maximum density found across southern central Germany (Fig. 1). Here, the derecho density of moderateand high-end-intensity events reaches 0.72 per year or about 3 derechos every 4 years for $200 \mathrm{~km} \times 200 \mathrm{~km}$ grid boxes. Derechos are less frequent across Germany compared to the eastern United States, where four moderate- and high-endintensity derechos can be expected every 3 years for similar grid boxes in the most affected region from Minnesota and Iowa to Pennsylvania and from the eastern parts of the southern Great Plains to the lower Mississippi Valley (Coniglio and Stensrud, 2004). The derecho frequency of southern Germany is comparable to that of the Appalachian Mountains in the United States (Coniglio and Stensrud, 2004). Fewer derechos have been found across northern Germany. Along the coasts of the North and Baltic seas, derechos are rare, with only 0.28 to 0.33 events per year or about 1 event in 3-4 years. The rarity of derechos along the coast is similar to the rarity of thunderstorms (Wapler, 2013) and the low mixed-layer CAPE along the coast relative to locations farther south (Siedlecki, 2009). The fraction of derechos occurring in the cold season (October to March) increased from south to north.

German derechos are less intense compared to those in the United States. A total of 5 of 40 (13\%) German derechos reached high-end intensity according to the definition of Coniglio and Stensrud (2004), with 19 (48\%) being of moderate intensity and $16(40 \%)$ being of low-end intensity (Fig. 2a). A relatively small fraction of German derechos are of high-end intensity compared to $23 \%$ in the United States 
Table 1. Derechos found between 1997 and 2014. Countries of start and end points are abbreviated as GER (Germany), AUT (Austria), FRA (France), SVK (Slovakia), CZE (Czechia), POL (Poland), DEN (Denmark), SUI (Switzerland), BEL (Belgium), NED (Netherlands), SRB (Serbia), SCO (Scotland), ENG (England), and CRO (Croatia), respectively. Cardinal directions have been abbreviated for space throughout the table; $\mathrm{C}$ stands for central.

\begin{tabular}{|c|c|c|c|c|c|}
\hline Number & Start time (UTC) & Path length $(\mathrm{km})$ & Duration (h) & Intensity & Path \\
\hline 1 & 11 April 1997 02:00:00 & 1620 & 16 & moderate & NW GER-E AUT \\
\hline 2 & 5 February 1999 00:00:00 & 660 & 10 & moderate & N GER-C GER \\
\hline 3 & 2 June 1999 14:00:00 & 420 & 6 & moderate & SW GER-C GER \\
\hline 4 & 2 June 1999 15:00:00 & 600 & 7 & high & E FRA-SE GER \\
\hline 5 & 3 December 1999 15:00:00 & 560 & 6 & low & NW GER-E GER \\
\hline 6 & 2 July 2000 14:00:00 & 550 & 7 & moderate & N FRA-W GER \\
\hline 7 & 4 July 2000 11:00:00 & 630 & 7 & moderate & SE GER-N SVK \\
\hline 8 & 6 July 2001 17:00:00 & 450 & 6 & moderate & E FRA-C GER \\
\hline 9 & 28 December 2001 09:00:00 & 750 & 12 & low & NW GER-N CZE \\
\hline 10 & 28 January 2002 12:00:00 & 930 & 12 & low & N GER-SE POL \\
\hline 11 & 28 January 2002 13:00:00 & 430 & 5 & low & NW GER-E GER \\
\hline 12 & 29 April 2002 12:00:00 & 410 & 6 & low & W GER-E GER \\
\hline 13 & 10 July 2002 16:00:00 & 600 & 7 & high & SE GER-E DEN \\
\hline 14 & 28 January 2003 06:00:00 & 440 & 6 & low & W GER-SE GER \\
\hline 15 & 19 May 2003 15:00:00 & 620 & 6 & low & N SUI-C CZE \\
\hline 16 & 14 June 2003 06:00:00 & 1000 & 15 & moderate & N FRA-SE AUT \\
\hline 17 & 15 December 2003 21:00:00 & 700 & 6 & low & N GER-E CZE \\
\hline 18 & 12 August 2004 15:00:00 & 590 & 9 & low & N SUI-E AUT \\
\hline 19 & 19 November 2004 06:00:00 & 850 & 12 & moderate & S GER-SE POL \\
\hline 20 & 12 February 2005 15:00:00 & 610 & 7 & low & S BEL-SE GER \\
\hline 21 & 29 July 2005 14:00:00 & 740 & 11 & high & NW SUI-E GER \\
\hline 22 & 20 May 2006 12:00:00 & 600 & 8 & moderate & W GER-NW CZE \\
\hline 23 & 18 January 2007 13:00:00 & 1100 & 11 & moderate & N NED-SE POL \\
\hline 24 & 21 June 2007 06:00:00 & 1020 & 15 & moderate & W SUI-N SVK \\
\hline 25 & 22 February 2008 15:00:00 & 1150 & 13 & moderate & NW DEN-E POL \\
\hline 26 & 1 March 2008 02:00:00 & 1520 & 16 & high & W NED-C SRB \\
\hline 27 & 25 June 2008 16:00:00 & 570 & 6 & low & E GER-C SVK \\
\hline 28 & 26 May 2009 12:00:00 & 570 & 8 & moderate & SW SUI-SW CZE \\
\hline 29 & 23 July 2009 17:00:00 & 520 & 7 & moderate & SE GER-N SVK \\
\hline 30 & 23 July 2009 15:00:00 & 670 & 7 & low & E GER-C POL \\
\hline 31 & 12 July 2010 09:00:00 & 650 & 6 & moderate & S BEL-SW DEN \\
\hline 32 & 14 July 2010 12:00:00 & 500 & 5 & moderate & CENTR FRA-C NED \\
\hline 33 & 22 June 2011 12:00:00 & 450 & 6 & low & SW GER-E GER \\
\hline 34 & 22 June 2011 13:00:00 & 550 & 5.5 & moderate & E FRA-SE GER \\
\hline 35 & 24 August 2011 16:00:00 & 440 & 6 & low & W GER-E GER \\
\hline 36 & 4 August 2013 10:00:00 & 790 & 10 & low & N SUI-W SVK \\
\hline 37 & 6 August 2013 12:00:00 & 750 & 10 & moderate & SW GER-E GER \\
\hline 38 & 5 December 2013 05:00:00 & 1160 & 13 & high & N SCO-NW GER \\
\hline 39 & 3 January 2014 14:00:00 & 680 & 7 & low & N FRA-N GER \\
\hline 40 & 21 October 2014 13:00:00 & 1600 & 15 & moderate & S ENG-E CRO \\
\hline
\end{tabular}

(55 of 244 events, Coniglio and Stensrud, 2004) $)^{2}$. Additionally, a relatively large fraction of German derechos are of low-end intensity, compared to $30 \%$ in the United States (73 of 244 events analyzed by Coniglio and Stensrud, 2004).

The path length of German derechos is between 400 and $600 \mathrm{~km}$ for 15 of 40 events $(38 \%)$ and between 600 and

\footnotetext{
${ }^{2}$ The intensity classification by Coniglio and Stensrud (2004) also includes damage reports that could result in a larger fraction of moderate- and high-end-intensity events.
}

$800 \mathrm{~km}$ for another 15 of 40 events (38\%). A total of 10 of the 40 derecho paths $(25 \%)$ exceed 800 km (Fig. 2b). Germany extends about $600 \mathrm{~km}$ from west to east and $850 \mathrm{~km}$ from north to south, and it is possible that its limited areal extent and the lower detection rate of derecho paths beyond the German borders leads to shorter derecho paths for some of the analyzed events. However, it was possible to follow derecho paths farther into neighboring countries based on in- 

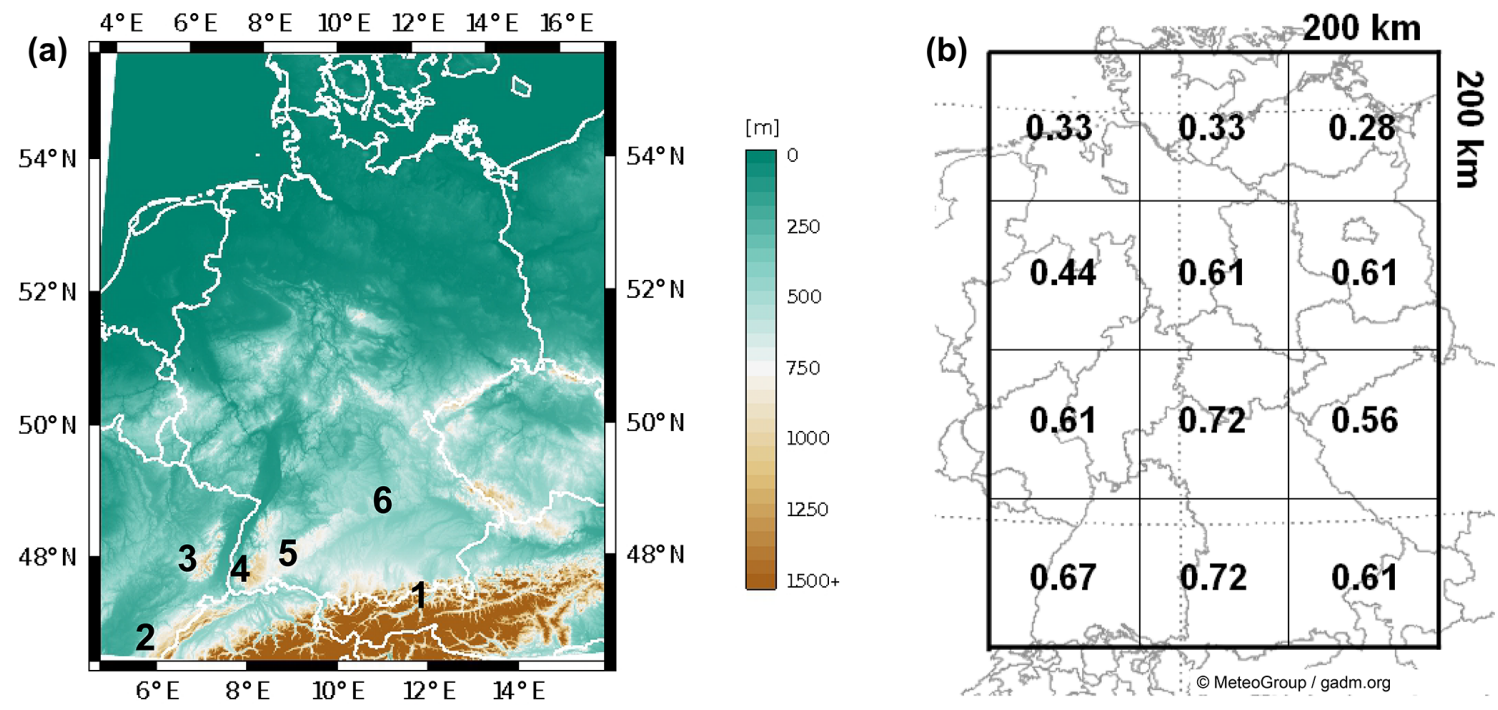

Figure 1. (a) Topography of Germany. Terrain height (m) is given by shading according to the color bar. Mountains mentioned in the text are highlighted by numbers: 1 - Alps, 2 - Swiss Jura, 3 - Vosges, 4 - Black Forest, 5 - Swabian Jura, 6 - Franconian Jura. (b) The number of moderate- and high-end-intensity derechos affecting grid boxes with $200 \mathrm{~km}$ side length across Germany per year (1997-2014).
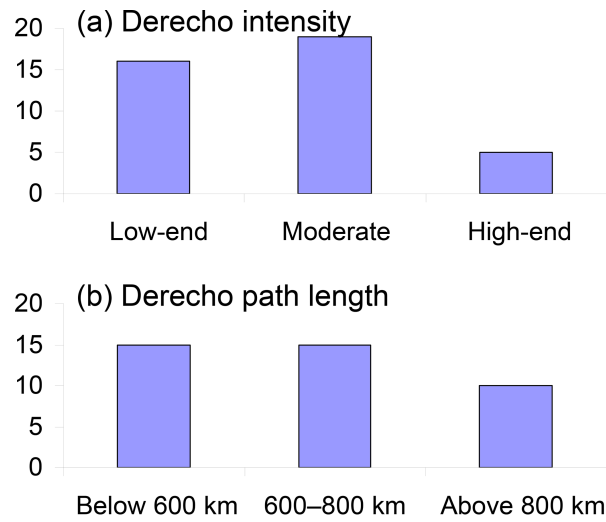

20
15
10
5
0

(c) Derecho duration
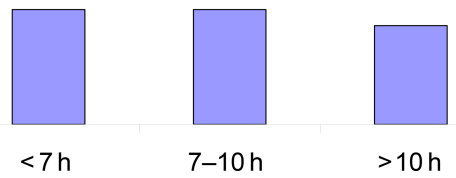

Figure 2. Characteristics of derechos (1997-2014): (a) intensity, (b) path length, and (c) duration.

ternationally distributed wind reports. Some events could be tracked as far as Scotland or Serbia.

German derechos occur most commonly in June and July, as 16 of 40 derechos $(40 \%)$ fall within these 2 months (Fig. 3). In late summer, the derecho frequency drops rapidly, and September is the only month with no recorded derecho during the 18-year period. This clear seasonal derecho frequency maximum is comparable to that in the United States (e.g., Coniglio et al., 2004). From December to February,

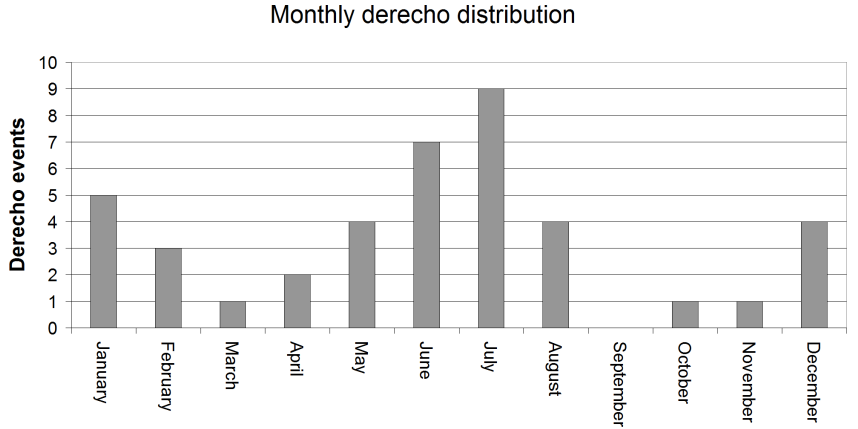

Figure 3. Seasonal distribution of derecho events in Germany (1997-2014).

there is another peak in the German derecho distribution. These 3 months account for 12 derechos (30\%), and January is the month with the third-highest derecho number during the analyzed time period. The secondary maximum during the cold season also occurs in the United States, although it is less pronounced; October to March contribute less than $25 \%$ of derechos in the United States (Ashley and Mote, 2005), compared to $38 \%$ for the same period in Germany.

The two seasonal peaks of derecho occurrence are associated with distinct flow patterns at middle levels. A cluster analysis of the $500 \mathrm{hPa}$ geopotential fields indicates two main clusters that account for 39 of 40 derechos (Fig. 4). There is a warm-season cluster that represents 22 derechos that occurred between May and August. The 20 May 2006 event is the only example out of 23 events that occurred between May to August and is not included in this cluster. The coldseason cluster contains 16 of 17 derechos that occurred be- 
tween October and April plus the one on 20 May 2006. There is one event that is not represented in these two clusters, 11 April 1997. From a manual analysis, this event resembles the cold-season cluster, with high geopotential across the Atlantic Ocean to the west and lower geopotential across eastern Europe. In contrast, the warm-season cluster indicates low geopotential across western Europe and higher geopotential across eastern Europe. We therefore assigned the remaining event to the cold-season cluster. In the following sections, we name derechos of the warm-season cluster "warm-season-type derechos"; derechos of the other cluster (including the 20 May 2006 event) and the event of 11 April 1997 are "cold-season-type derechos".

\subsection{Warm-season-type derechos}

In the 18-year analysis, 22 of 40 derechos (55\%) are of the warm-season type. They form from May to August with a frequency peak in early July (Fig. 3). The diurnal cycle of diabatic heating is likely important for these events. A total of 17 of the 22 warm-season-type derechos (77\%) start in the afternoon and early evening between 12:00 and 17:00 UTC, corresponding to 14:00 and 19:00 CEST, and a further three $(14 \%)$ between 09:00 and 12:00 UTC (11:00 and 14:00 CEST, respectively) (Fig. 5a). Their intensity is high-end for 3 of $22(14 \%)$ and low-end for 7 of 22 (32\%); their average path length is $620 \mathrm{~km}$. Almost all of these derechos move from the southwest to the northeast across Germany (Fig. 6a). They frequently start north of the Swiss Alps or over the northern slopes of the Jura Mountains across Switzerland and France (Fig. 1a). Over Germany, 12 of 22 warm-season-type derechos follow either eastward paths along the northern slopes of the Alps, eventually entering Austria or paths along the northwestern slopes of the Swabian and Franconian Jura mountains toward central and eastern Germany. In contrast to the relatively high derecho frequency in southern Germany, only two warm-seasontype events affect northern Germany in the 18-year period (Fig. 6a). Warm-season-type derechos that affect northern Germany move from south to north, whereas the events close to the Alps have a large eastward component of motion.

The average synoptic-scale $500 \mathrm{hPa}$ flow of the warmseason-type cluster shows a western European trough and a strong southwesterly flow across Germany (Fig. 4a). The warm-season type thus typically occurs downstream of troughs to the west of Germany. As indicated by the anticyclonic curvature of the average geopotential contour lines over eastern Germany, some derechos move into the downstream ridge during their lifetime. These events can be a challenge to operational forecasters because they occur in regions where severe storms might not be necessarily expected. Furthermore, derechos of the warm-season type frequently occur in derecho families with a recurrent large-scale weather pattern (Bentley and Sparks, 2003; Ashley et al., 2004). There were two events that followed each other on
2 and 4 July 2000, 12 and 14 July 2010, and 4 and 6 August 2013. Moreover, there were two derechos per day on 2 June 1999, 23 July 2009, and 22 June 2011.

In addition to the synoptic-scale flow on derecho days, the thermodynamic environment can help to assess the derecho potential. We analyzed 23 proximity soundings for warmseason-type derechos (right columns of Table 2) with respect to sounding parameters such as mixed-layer CAPE and vertical wind shear (Fig. 7). We used Púčik et al. (2015) and Taszarek et al. (2017) to compare our results with a larger set of sounding parameters across central Europe. Púčik et al. (2015) identified 1135 proximity soundings by using a maximum distance of $150 \mathrm{~km}$ from severe wind reports occurring up to $3 \mathrm{~h}$ after the sounding time. That study covered western and central Europe for March-October 2008-2013. Taszarek et al. (2017) found 828 proximity soundings by using a maximum distance of $125 \mathrm{~km}$ and time differences of up to $2 \mathrm{~h}$ before and $4 \mathrm{~h}$ after the sounding time. This study covered the 2009-2015 (March-October) warm seasons across western and central Europe. Additionally, Taszarek et al. (2017) present further categories of proximity soundings, such as non-severe thunderstorms (8361 soundings) and extremely severe convective wind gusts $\left(33+\mathrm{m} \mathrm{s}^{-1} ; 23\right.$ soundings). We compare medians of sounding parameters of both studies with those of German derechos. Furthermore, box-andwhisker plots of German derechos (Fig. 7) are compared with those presented in Taszarek et al. (2017, their Figs. 3 and 8) to analyze the ability of sounding parameters to discriminate between environments of derechos and other categories of thunderstorms.

The $0-6 \mathrm{~km}$ vertical wind shear in warm-season-type derecho proximity soundings in Germany is relatively strong. The median is $20.1 \mathrm{~m} \mathrm{~s}^{-1}$ (Fig. 7h and Table 3) and can be compared to a median of $13.8 \mathrm{~m} \mathrm{~s}^{-1}$ for severe convective wind gusts indicated by Taszarek et al. (2017). Additionally, the median of derecho $0-6 \mathrm{~km}$ shear is slightly higher than the median of the extremely severe wind gust category (about $19.5 \mathrm{~m} \mathrm{~s}^{-1}$, Taszarek et al., 2017). Deep-layer shear discriminates between derecho and non-severe thunderstorm environments, as the median of $20.1 \mathrm{~m} \mathrm{~s}^{-1}$ almost reaches the 90th percentile of non-severe thunderstorm environments, which is about $20.5 \mathrm{~m} \mathrm{~s}^{-1}$ (Taszarek et al., 2017). The 0$6 \mathrm{~km}$ shear's median of derecho environments is also above the upper quartile of the severe convective wind gust category (about $19.5 \mathrm{~m} \mathrm{~s}^{-1}$, Taszarek et al., 2017). Compared to the work of Púčik et al. (2015) that includes cold-season wind events, the median of 0-6 km shear of warm-seasontype derechos is still rather high compared to the median of the severe wind gust category $\left(16.1 \mathrm{~m} \mathrm{~s}^{-1}\right)$.

We found similar results based on vertical wind shear at lower levels. For $0-3 \mathrm{~km}$ shear, the derecho median is $14.9 \mathrm{~m} \mathrm{~s}^{-1}$ (Fig. 7g and Table 3) compared to a median of about $9.8 \mathrm{~m} \mathrm{~s}^{-1}$ and an upper quartile of $14.2 \mathrm{~m} \mathrm{~s}^{-1}$ for severe convective wind gusts and a 90th percentile of $13.9 \mathrm{~m} \mathrm{~s}^{-1}$ for non-severe thunderstorms given by Taszarek 

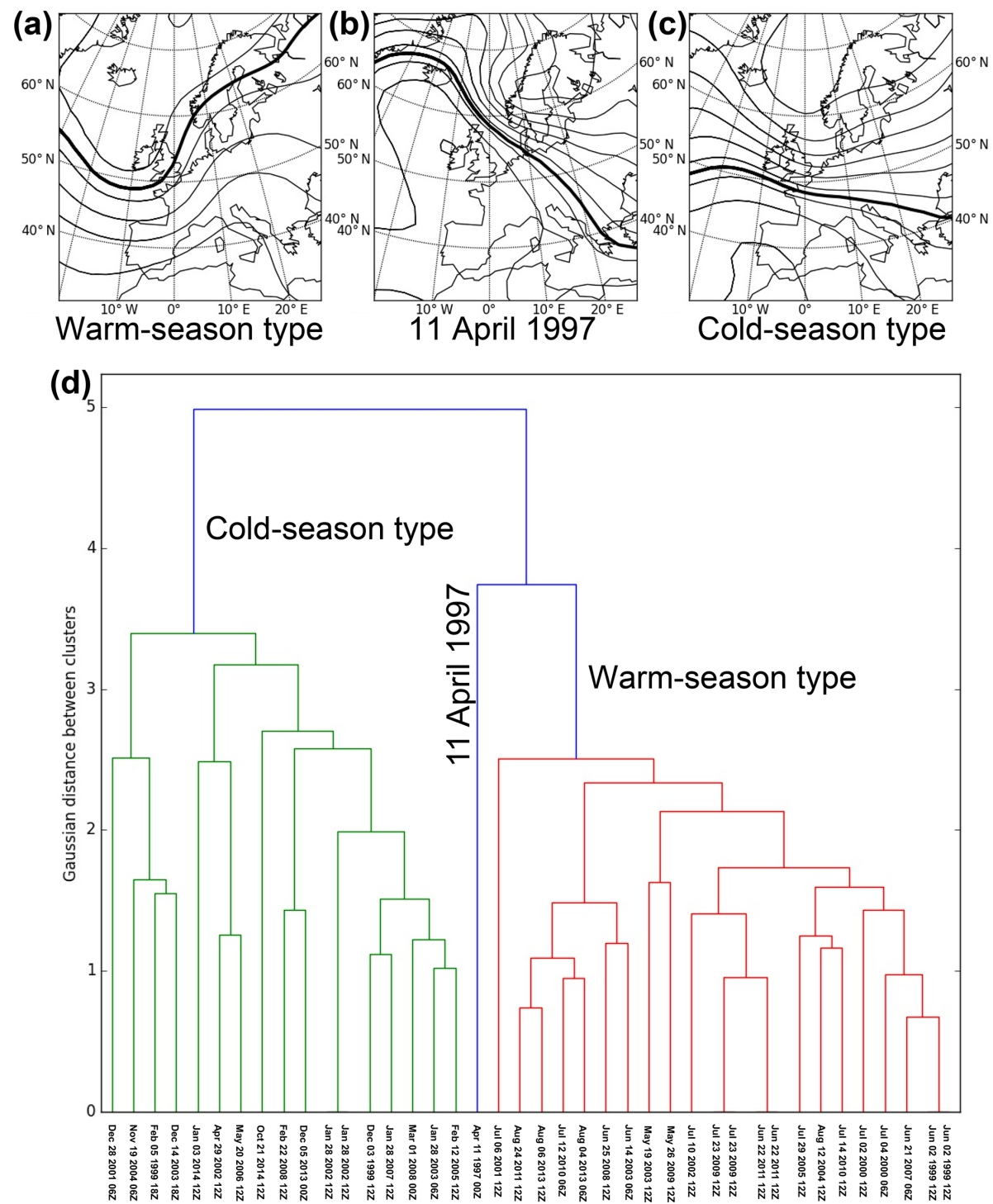

Figure 4. (a) Averaged $500 \mathrm{hPa}$ geopotential field of the warm-season-type derecho cluster (1997-2014). Isohypses are displayed in 80 m intervals; the $5600 \mathrm{~m}$ isohypse is highlighted by the thick line. (b) The 500 hPa geopotential field of 11 April 1997 00:00:00 UTC. (c) Averaged $500 \mathrm{hPa}$ geopotential field of the cold-season-type derecho cluster (1997-2014). (d) Dendrogram of the cluster analysis of 500 hPa geopotential fields in German derecho events (1997-2014). Dates of the analysis fields are given below each event line. The names of the clusters $(\mathbf{a}-\mathbf{c})$ are also given in the dendrogram. The maps in $(\mathbf{a}-\mathbf{c})$ have been produced with the python module basemap.

et al. (2017). For the $0-1 \mathrm{~km}$ shear, the median increases from about $3.5 \mathrm{~m} \mathrm{~s}^{-1}$ over $5 \mathrm{~m} \mathrm{~s}^{-1}$ to about $5.8 \mathrm{~m} \mathrm{~s}^{-1}$ for, respectively, non-severe thunderstorms, severe convective wind gusts, and extremely severe convective wind gusts given by Taszarek et al. (2017). It reaches $6.7 \mathrm{~m} \mathrm{~s}^{-1}$ for derechos (Fig. 7f and Table 3). Púčik et al. (2015) indicated a rather strong median of $0-1 \mathrm{~km}$ shear for severe convective wind reports that is about the same magnitude as the median for derechos $\left(6.6 \mathrm{~m} \mathrm{~s}^{-1}\right.$ compared to $\left.6.7 \mathrm{~m} \mathrm{~s}^{-1}\right)$. Nonetheless, 0 $1 \mathrm{~km}$ shear does not discriminate well between derecho environments and those of other categories. For example, the derecho median of $0-1 \mathrm{~km}$ shear is only slightly higher than the upper quartile for the non-severe thunderstorm category $\left(6 \mathrm{~m} \mathrm{~s}^{-1}\right.$ Taszarek et al., 2017), and for one proximity derecho sounding, $0-1 \mathrm{~km}$ shear is as weak as $1.6 \mathrm{~m} \mathrm{~s}^{-1}$ (Fig. 7f).

In addition to vertical wind shear, the equilibrium level temperature of derecho soundings could discriminate between non-severe thunderstorm and derecho environments. The median equilibrium level temperature is $-48^{\circ} \mathrm{C}$ (Fig. $7 \mathrm{~b}$ and Table 3), which is below the 90th percentile of non-severe thunderstorm environments, and it is also about $20^{\circ} \mathrm{C}$ below the medians of severe and extremely severe convective-wind environments (Taszarek et al., 2017). The median of mixed-layer CAPE of warm-season-type derechos 
Table 2. Proximity soundings of derechos between 1997 and 2014. The left column lists soundings of cold-season-type derechos, and the right column lists soundings of warm-season-type derechos. Sounding sites are given by their WMO station identifier code. Soundings marked with ${ }^{a}$ are chosen despite the fact that the derecho moved across the sounding site $3 \mathrm{~h}$ after the sounding launch instead of $2 \mathrm{~h}$. For the sounding marked with ${ }^{b}$, there was no clear evidence that it was crossed by the derecho before or after the launch time.

\begin{tabular}{lrlr}
\hline Date and time (UTC) & Sounding no. & Date and time (UTC) & Sounding no. \\
\hline 11 April 1997, 12:00:00 & $12425^{\mathrm{b}}$ & 2 June 1999, 12:00:00 & 10618 \\
5 February 1999, 00:00:00 & 10035 & 2 June 1999, 12:00:00 & 10739 \\
5 February 1999, 06:00:00 & 10393 & 4 July 2000, 12:00:00 & 11035 \\
5 February 1999, 12:00:00 & $11520^{\mathrm{a}}$ & 2 July 2000, 12:00:00 & 07145 \\
5 February 1999, 12:00:00 & 10771 & 4 July 2000, 12:00:00 & 10868 \\
28 December 2001, 12:00:00 & 10238 & 7 July 2001, 12:00:00 & 10868 \\
28 December 2001, 12:00:00 & 10410 & 10 July 2002, 18:00:00 & 10393 \\
28 December 2001,18:00:00 & 11520 & 19 May 2003, 18:00:00 & 11520 \\
28 January 2002, 12:00:00 & 10410 & 14 June 2003, 12:00:00 & 10739 \\
28 January 2002, 18:00:00 & 10393 & 29 July 2005, 12:00:00 & 06610 \\
29 April 2002, 12:00:00 & 10410 & 30 July 2005, 00:00:00 & 12425 \\
29 April 2002, 12:00:00 & 06260 & 21 June 2007, 12:00:00 & 10739 \\
28 January 2003, 12:00:00 & 11035 & 26 May 2009, 18:00:00 & 10771 \\
28 January 2003, 12:00:00 & 06610 & 26 May 2009, 18:00:00 & 11520 \\
15 December 2003,00:00:00 & 11520 & 23 July 2009, 12:00:00 & 11520 \\
15 December 2003,00:00:00 & 10548 & 22 June 2011, 12:00:00 & 10618 \\
19 November 2004, 06:00:00 & 10771 & 22 June 2011, 12:00:00 & 10739 \\
19 November 2004, 12:00:00 & $11952^{\mathrm{a}}$ & 22 June 2011, 18:00:00 & 10771 \\
12 February 2005, 18:00:00 & 10618 & 22 June 2011, 18:00:00 & 10393 \\
20 May 2006, 12:00:00 & 10410 & 24 August 2011, 18:00:00 & 10548 \\
20 May 2006, 12:00:00 & 07145 & 4 August 2013, 12:00:00 & 10739 \\
20 May 2006, 12:00:00 & 06260 & 6 August 2013, 12:00:00 & 10739 \\
20 May 2006, 18:00:00 & 10771 & 6 August 2013, 12:00:00 & 06610 \\
18 January 2007, 18:00:00 & 10393 & & \\
23 February 2008,00:00:00 & 10393 & & \\
23 February 2008,00:00:00 & $12425^{\mathrm{a}}$ & & \\
1 March 2008, 00:00:00 & $06260^{\mathrm{a}}$ & & \\
1 March 2008, 06:00:00 & 10618 & & \\
5 December 2013, 12:00:00 & $10035^{\mathrm{a}}$ & & \\
21 October 2014, 12:00:00 & 07145 & & \\
21 October 2014, 18:00:00 & 10771 & & \\
\hline
\end{tabular}

Table 3. Median values of sounding parameters derived from derechos of the warm-season (top) and cold-season (bottom) type. From left to right: mixed-layer CAPE (MLCAPE), mixing ratio (MIXR), 0-6 km shear (SHR 0-6), 0-3 km shear (SHR 0-3), 0-1 km shear (SHR 0-1), equilibrium level temperature (ELT), and level of free convection (LFC).

\begin{tabular}{llllllll}
\hline Derecho type & MLCAPE & MIXR & SHR 0-6 & SHR 0-3 & SHR 0-1 & ELT & LFC \\
\hline Warm-season-type & $513 \mathrm{~J} \mathrm{~kg}^{-1}$ & $10.62 \mathrm{~g} \mathrm{~kg}^{-1}$ & $20.1 \mathrm{~m} \mathrm{~s}^{-1}$ & $14.9 \mathrm{~m} \mathrm{~s}^{-1}$ & $6.7 \mathrm{~m} \mathrm{~s}^{-1}$ & $-48^{\circ} \mathrm{C}$ & $753 \mathrm{hPa}$ \\
Cold-season-type & $3 \mathrm{~J} \mathrm{~kg}^{-1}$ & $5.16 \mathrm{~g} \mathrm{~kg}^{-1}$ & $34.5 \mathrm{~m} \mathrm{~s}^{-1}$ & $23.1 \mathrm{~m} \mathrm{~s}^{-1}$ & $21.2 \mathrm{~m} \mathrm{~s}^{-1}$ & $4-7.5^{\circ} \mathrm{C}$ & $867 \mathrm{hPa}$ \\
\hline
\end{tabular}

in Germany is $513 \mathrm{~J} \mathrm{~kg}^{-1}$. This value is higher than the medians of mixed-layer CAPE for non-severe thunderstorms and severe convective wind gusts presented in Taszarek et al. (2017), which are about 100 and $250 \mathrm{~J} \mathrm{~kg}^{-1}$, respectively, but below the median for severe convective wind reports in Púčik et al. (2015) that reach $695 \mathrm{~J} \mathrm{~kg}^{-1}$ of the most unstable
$\mathrm{CAPE}^{3}$. Furthermore, the upper quartile of mixed-layer CAPE for non-severe thunderstorms is well below the median of derechos (375 $\mathrm{J} \mathrm{kg}^{-1}$, Taszarek et al., 2017), thus mixed-layer CAPE discriminates between derecho and nonsevere thunderstorm environments. Other thermodynamic parameters are less useful for anticipating derecho potential.

\footnotetext{
${ }^{3}$ The most unstable CAPE and mixed-layer CAPE are calculated differently and cannot be compared directly.
} 

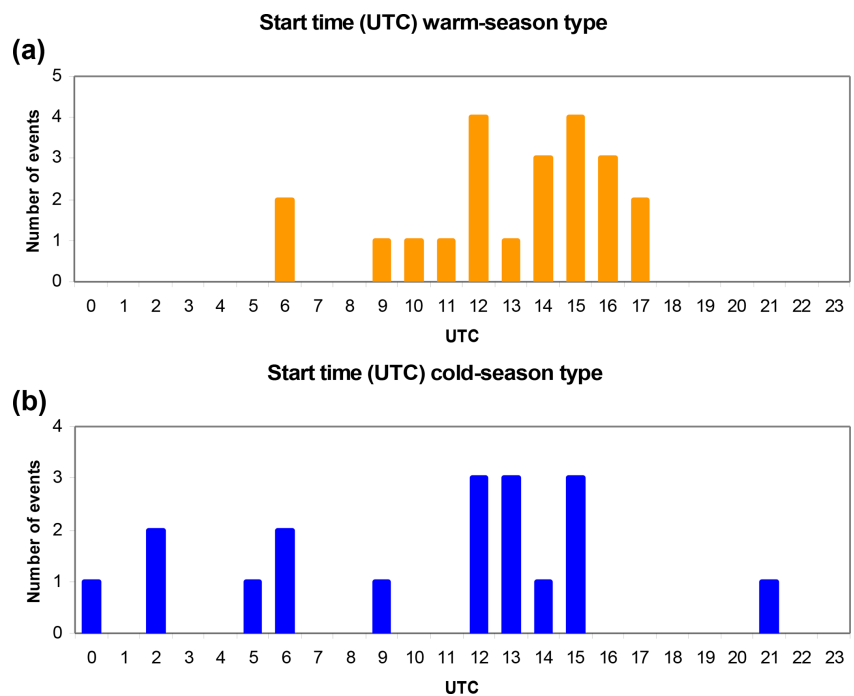

Figure 5. Start time (UTC) of derechos (1997-2014) of the warmseason type (a) and the cold-season type (b).

Low-level mixing ratio is not useful for discriminating between derecho and non-severe thunderstorm environments or between non-severe thunderstorm and severe convective wind gust environments, although its median is slightly higher for German derechos with $10.6 \mathrm{~g} \mathrm{~kg}^{-1}$ (Fig. 7c and Table 3) compared to approximately $9.7 \mathrm{~g} \mathrm{~kg}^{-1}$ for non-severe thunderstorms and approximately $10.3 \mathrm{~g} \mathrm{~kg}^{-1}$ for severe convective wind gusts (Taszarek et al., 2017). Finally, derechos can form when the level of free convection (LFC) is close to the ground (e.g., $1147 \mathrm{~m}$ ) or at greater heights (e.g., $4227 \mathrm{~m}$ ). There is no tendency for derechos to form in association with particularly low or high LFC (Fig. 7e and Table 3).

In summary, German warm-season-type derecho environments are characterized by relatively strong vertical wind shear and cold equilibrium levels compared to other convective events across central Europe. Additionally, mixedlayer CAPE is relatively large. Compared to derecho proximity soundings from the United States, $0-6 \mathrm{~km}$ vertical wind shear in German warm-season derecho environments is rather strong. For example, the lower and upper quartiles of 0-6 km vertical wind shear of this study are higher compared to the results of Evans and Doswell (2001) (15.9 and $24.7 \mathrm{~m} \mathrm{~s}^{-1}$ compared to 11.8 and $20.0 \mathrm{~m} \mathrm{~s}^{-1}$, respectively). The mixed-layer CAPE values of German warm-season derechos are low compared to those in the United States. For example, for derecho proximity soundings given in Evans and Doswell (2001), the lower quartile of mixed-layer CAPE ${ }^{4}$ is $1097 \mathrm{~J} \mathrm{~kg}^{-1}$, which slightly exceeds the upper quartile in the

\footnotetext{
${ }^{4}$ Evans and Doswell (2001) also include cold-season derechos and calculate mixed-layer CAPE for the lowest $100 \mathrm{~m}$ mixed-layer parcel instead of the lowest $500 \mathrm{~m}$ mixed-layer parcels used in our study.
}
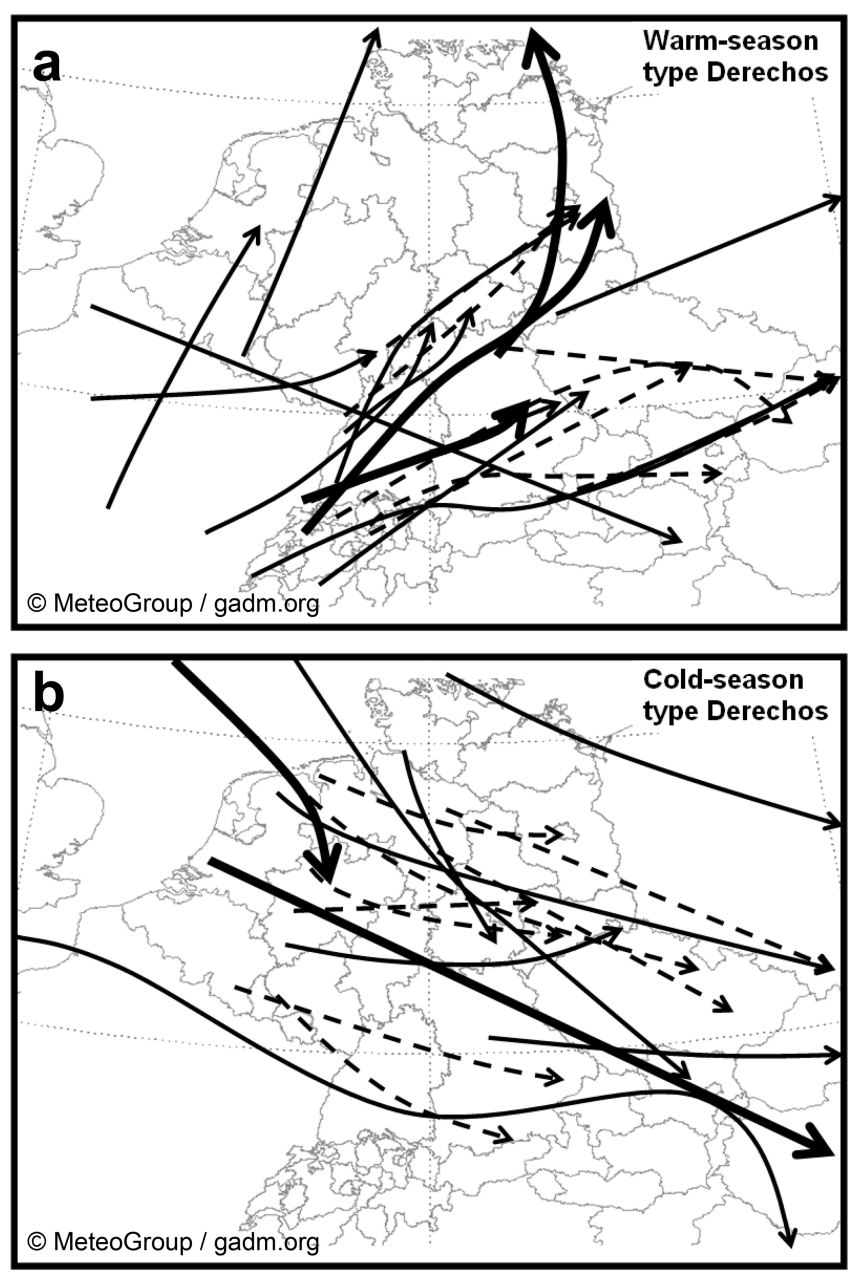

Figure 6. Tracks of derechos (1997-2014) of the warm-season type (a) and the cold-season type (b). Thick lines, thin lines, and broken lines relate to high-end-, moderate-, and low-end-intensity derechos.

German distribution (1061 J kg-1, Fig. 7a). Derechos with low CAPE have been also analyzed in the United States (Evans and Doswell, 2001; Burke and Schultz, 2004). These events indicated similar midlevel synoptic-scale flow ahead of advancing high-amplitude troughs (strongly forced synoptic situations; Evans and Doswell, 2001, their Fig. 1b). Next to differences in sounding parameters, German warmseason-type derechos form later in the year compared to the results of Bentley and Sparks (2003), with an annual maximum in early July in Germany compared to May to July in the United States. For the United States, the location of the monthly maximum of derecho activity moves northward in the spring and summer (Bentley and Sparks, 2003). Likewise, the later derecho maximum in Germany may be related to its high latitude and the associated average seasonal CAPE distribution. This is in accordance to the lightning frequency across central Europe (Rädler et al., 2018). 


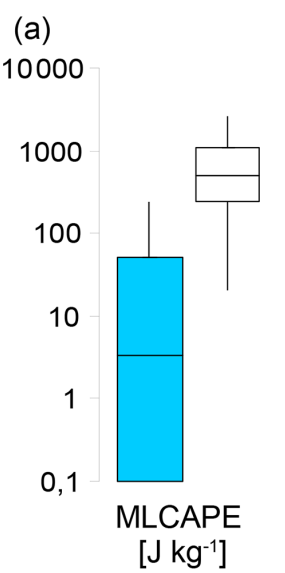

(b)
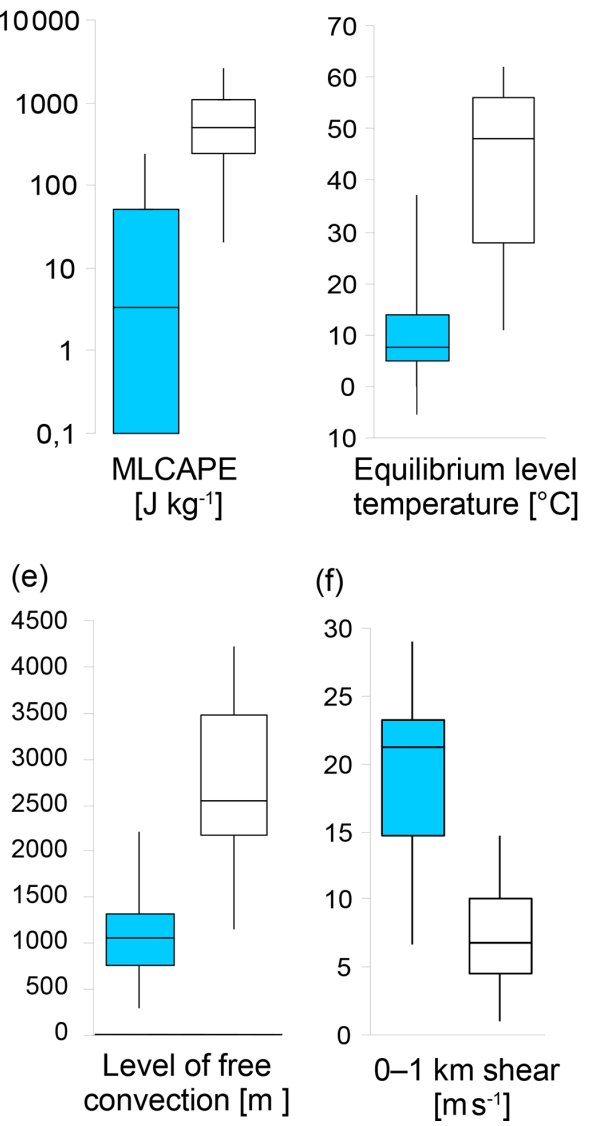

(c)

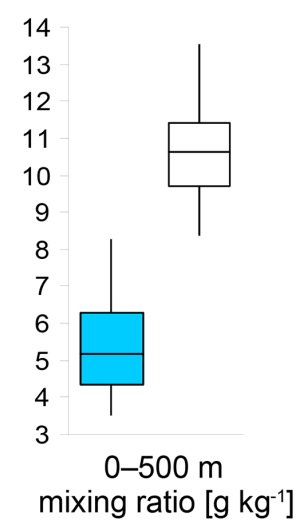

(g)

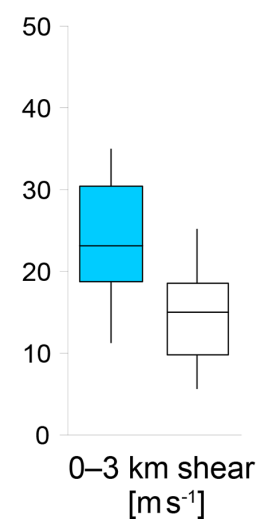

(d)

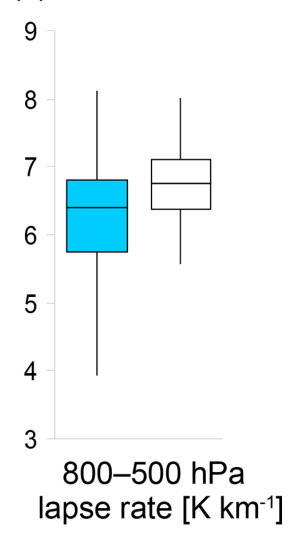

(h)

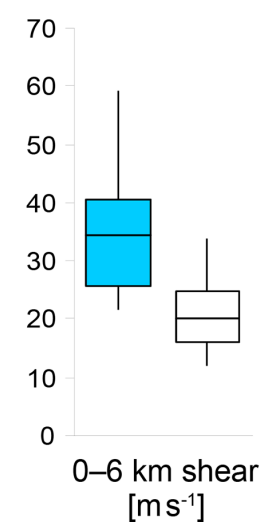

Figure 7. Box-and-whisker plots of warm-season-type and cold-season-type derecho proximity soundings (1997-2014). Boxes (blue for the cold-season type) give the upper and lower quartiles of the distributions, the end of the vertical thin lines give the maxima and minima, and the horizontal thick lines give the medians: (a) mixed-layer CAPE, (b) equilibrium level temperature, (c) 0-500 m mixing ratio, (d) 800$500 \mathrm{hPa}$ lapse rate, (e) level of free convection, (f) 0-1 km vertical wind shear, (g) 0-3 km vertical wind shear, and (h) 0-6 km vertical wind shear.

\subsection{Cold-season-type derechos}

A total of 18 of the 40 derechos (45\%) are of the cold-season type that mostly form during the secondary annual frequency maximum from December to February (Fig. 3). Only three derechos are assigned to the cold-season type after 1 March (11 April 1997, 29 April 2002, 20 May 2006). During the winter, diurnal heating is weak in Germany. Consequently, a less distinct diurnal cycle is present for cold-season-type derechos in comparison to the warm-season type (Figs. 5a and 5b). A total of 7 of 18 (39\%) cold-season-type derechos start between 18:00 and 06:00 UTC (19:00 and 07:00 CET, respectively), when there is no insolation (Fig. 5b). Nonetheless, diurnal heating has some influence, as indicated by a sharp frequency maximum in the early afternoon from 12:00 to $15: 00$ UTC (13:00 to $16: 00 \mathrm{CET}$ ), when 10 of 18 (56\%) cold-season-type derechos start (Fig. 5b). The intensity of the cold-season type is high-end for 2 of $18(11 \%)$ and low-end for 9 of $18(50 \%)$ events. On average, cold-season-type derechos are slightly weaker than the warm-season type given the smaller fraction of high-end intensity and a larger fraction of low-end intensity compared to the warm-season type (14\% and $32 \%$, respectively). However, the most intense derecho in the dataset is of the cold-season type and occurred on 1 March 2008. Moreover, the average path length of the cold-season type is $880 \mathrm{~km}$, which is 1.4 times the average path length of the warm-season type (path lengths are given in Table 1).

In contrast to the warm-season type, most cold-seasontype derechos occur across central Germany (Fig. 6b). A total of 4 events start over the North Sea, and a further 10 start over northwestern Germany, Belgium, and the Netherlands. This regional variability could be related to the distance to the North Sea, which likely serves as a source of lowlevel humidity in the cold season. Furthermore, cold-seasontype derechos move typically from northwest to southeast across Germany; only two have more west-east-oriented paths (Fig. 6b). The motion of cold-season-type derechos is related to the large-scale flow. The cold-season type is as- 
sociated with a westerly to northwesterly $500 \mathrm{hPa}$ flow in the wake of low geopotential heights across eastern Europe (Fig. 4b, c). A comparable flow pattern has been described for cold-season bow echoes in the United States (Johns, 1982, 1984; Burke and Schultz, 2004). In many situations, a trough amplifies across Germany during the event, associated with upper-tropospheric PV intrusions down to the midlevel troposphere (not shown). Cold-season-type derechos occur in 11 out of 19 cold seasons, and some of these seasons are associated with groups of derechos: 2001/02 (three derechos), 2007/08 (two derechos), and 2013/14 (two derechos). There were no derechos in the cold-seasons 1997/98, 2000/01, 2005/06, 2008/09, 2009/10, 2010/11, 2011/12, and 2012/13.

To characterize the cold-season derecho environment, we analyzed 31 proximity soundings (left columns in Table 2). We compared sounding parameters to those of proximity soundings across central Europe given in Púčik et al. (2015) (for severe convective wind events) and across the United States presented by Burke and Schultz (2004) (for cold-season bow echoes). We found high-shear-low-CAPE environments (Sherburn and Parker, 2014): Cold-seasontype derecho environments are characterized by exceptionally strong $0-6 \mathrm{~km}$ shear that is calculated for 28 of the 31 soundings (Fig. 7h). It is at least $22 \mathrm{~m} \mathrm{~s}^{-1}$ and peaks at $59 \mathrm{~m} \mathrm{~s}^{-1}$, the median is $34.5 \mathrm{~m} \mathrm{~s}^{-1}$ (Table 3), which is slightly above the median of $0-6 \mathrm{~km}$ shear presented for severe convective-wind environments in Púčik et al. (2015) $\left(33.2 \mathrm{~m} \mathrm{~s}^{-1}\right)$. Strong deep-layer vertical wind shear is also common in cold-season bow echo environments in the continental United States, with a mean $0-5 \mathrm{~km}$ shear of $23 \mathrm{~m} \mathrm{~s}^{-1}$ (Burke and Schultz, 2004). For lower level shear, we found a $0-3 \mathrm{~km}$ shear median of $23.1 \mathrm{~m} \mathrm{~s}^{-1}$ and a $0-1 \mathrm{~km}$ shear median of $21.2 \mathrm{~m} \mathrm{~s}^{-1}$ (Fig. 7f,g and Table 3). The median of 0 $1 \mathrm{~km}$ shear of cold-season-type derechos is therefore slightly higher compared to cold-season severe convective-wind environments (18.1 $\mathrm{m} \mathrm{s}^{-1}$, Púčik et al., 2015). For cold-season bow echoes in the United States, $0-2.5 \mathrm{~km}$ shear is weaker than $0-1 \mathrm{~km}$ shear in German derechos. The mean $0-2.5 \mathrm{~km}$ shear is $14 \mathrm{~m} \mathrm{~s}^{-1}$, with $87 \%$ of proximity soundings having less than $20 \mathrm{~m} \mathrm{~s}^{-1}$ shear (Burke and Schultz, 2004).

A total of $41 \%$ of proximity soundings in German coldseason-type derechos have zero mixed-layer CAPE. The maximum and median of mixed-layer CAPE are 231 and $3 \mathrm{~J} \mathrm{~kg}^{-1}$, respectively, and the lower quartile is $0 \mathrm{~J} \mathrm{~kg}^{-1}$ (Fig. 7a and Table 3). This was not unexpected; proximity soundings of severe convective-wind events across central Europe show similar results, with a median most unstable CAPE of $14 \mathrm{~J} \mathrm{~kg}^{-1}$ (Púčik et al., 2015). Furthermore, although most cold-season bow echoes in the continental United States have higher most unstable CAPE, there are also long-lived bow echo proximity soundings with a most unstable CAPE of less than $100 \mathrm{~J} \mathrm{~kg}^{-1}$ (Burke and Schultz, 2004). In addition to low mixed-layer CAPE, German cold-seasontype derecho environments are characterized by low mois- ture in the lowest $500 \mathrm{~m}$ layer above the ground. The highest mean mixing ratio is $8.3 \mathrm{~g} \mathrm{~kg}^{-1}$, the median is $5.2 \mathrm{~g} \mathrm{~kg}^{-1}$ (Table 3), and the lowest mixing ratio is $3.5 \mathrm{~g} \mathrm{~kg}^{-1}$ (Fig. 7c and Table 3). These are rather low values; in the continental United States, Burke and Schultz (2004) presented a minimum of mean lowest $100 \mathrm{hPa}$ mixing ratio of $9 \mathrm{~g} \mathrm{~kg}^{-1}$ for nine long-lived cold-season bow echoes. Nonetheless, there is a low LFC in many German cold-season-type derecho soundings (median $1061 \mathrm{~m}$; Fig. 7e and Table 3), indicating high relative humidity of the low-level air mass.

The equilibrium level temperature in proximity soundings of cold-season-type derechos is high in some events, peaking at $+6^{\circ} \mathrm{C}$, with a median of $-7.5^{\circ} \mathrm{C}$ (Fig. 7b, Table 3). Although cold-season-type derechos do not need to be associated with thunderstorms by definition, all German events produced lightning, which becomes likely at sufficiently low equilibrium level temperatures (i.e., below $-10^{\circ} \mathrm{C}$; van den Broeke et al., 2005). Soundings with high equilibrium level temperatures are likely not representative for the particular derecho events for this reason. One example is the derecho proximity sounding at Bergen (WMO number 10238) for 12:00 UTC 28 December 2001. The sounding has zero mixed-layer CAPE, whereas the 12:00 UTC SYNOP at the same location reports a thunderstorm with graupel (not shown). Rapid changes of the local equilibrium level temperature can be expected to occur close to this cold-season-type derecho in the time between the balloon launch (10:47 UTC) and the thunderstorm observation (11:50 UTC). Forecasters have to be aware that soundings may not indicate the potential of convective storms in the vicinity of cold-season-type derechos.

In summary, cold-season-type derechos in Germany are associated with strong vertical wind shear with a median $0-6 \mathrm{~km}$ shear of $35 \mathrm{~m} \mathrm{~s}^{-1}$ and a median $0-1 \mathrm{~km}$ shear of $21 \mathrm{~m} \mathrm{~s}^{-1}$. At the same time, mixed-layer CAPE is low and soundings frequently have zero mixed-layer CAPE. Taking into account that German cold-season-type derechos have longer path lengths on average and are of similar intensity to warm-season-type derechos, we expected them to have a similar potential impact as warm-season-type derechos in Germany.

\section{Conclusions}

This work analyzes derecho potential across Germany. Based on the presented climatology, the derecho risk is higher than would be expected from previously published cases. Whereas four events had been published in 10 years between 2004 and 2014, 40 events were classified in the 18-year period, including 24 moderate- and high-end-intensity derechos. The highest regional derecho risk occurs in southern Germany with about three moderate- or high-end-intensity derechos in 4 years, a value of similar magnitude to the Appalachian mountains in the eastern United States (Coniglio 
and Stensrud, 2004). The spatial derecho density maximum across southern Germany overlaps with the maximum of averaged thunderstorm days across Germany (Piper et al., 2019). The highest yearly derecho number in Germany was four in 2003; no derechos formed in 1998 and 2012. German derechos are most frequent in June and July, consistent with the highest seasonal lightning frequency across Germany (Wapler, 2013). The winter season (October-March) contributes on average to $40 \%$ of the annual derecho number, although 8 of 18 winter seasons had no derechos. The relative contribution of German winter season derechos to the annual derecho number is large compared to the winter season in the United States, which contributes only $25 \%$ to the annual derecho number (Ashley and Mote, 2005), and also large with respect to the low average frequency of lightning in the winter season (Wapler, 2013).

According to a cluster analysis of the $500 \mathrm{hPa}$ flow across Europe, German derechos form in two distinct synopticscale situations. A total of 22 derechos correspond to the first derecho type that forms in strong southwesterly $500 \mathrm{hPa}$ flow downstream of a trough across the northeastern Atlantic Ocean and western Europe. Such weather patterns are also favorable for thunderstorms across Germany (Piper et al., 2019). This first derecho type only occurs in the summer months (May to August) and is thus named warm-season type accordingly. Based on our climatology, there is less mixed-layer CAPE in the pre-derecho region than expected from case studies of central European warm-season derechos. Median mixed-layer CAPE in this study is $500 \mathrm{~J} \mathrm{~kg}^{-1}$ versus mixed-layer CAPE between 1000 and $2500 \mathrm{~J} \mathrm{~kg}^{-1}$ in previous derecho case studies (Gatzen, 2004; Púčik et al., 2011; Hamid, 2012; Celiński-Mysław and Matuszko, 2014). Derechos in environments with limited CAPE have also been described in the United States (Evans and Doswell, 2001; Burke and Schultz, 2004) and are characterized by similar midlevel synoptic-scale flow ahead of advancing high-amplitude troughs (strongly forced synoptic situations; Evans and Doswell, 2001, their Fig. 1b).

We also compared the set of warm-season-type derecho proximity soundings with the results of studies on central European sounding analyses by Púčik et al. (2015) and Taszarek et al. (2017) to evaluate if derecho environments differ from those of non-severe thunderstorms or severe convective wind events. For example, the median mixedlayer CAPE of warm-season-type derechos is $513 \mathrm{~J} \mathrm{~kg}^{-1}$, compared to about $113 \mathrm{~J} \mathrm{~kg}^{-1}$ for non-severe thunderstorms (Taszarek et al., 2017); their equilibrium level temperature is $-48^{\circ} \mathrm{C}$, which is below the 90th percentile of non-severe thunderstorms (Taszarek et al., 2017). The best parameter to distinguish between environments of warm-season-type derechos and other convective events in Germany is $0-6 \mathrm{~km}$ shear, given that the median of $20.1 \mathrm{~m} \mathrm{~s}^{-1}$ is higher than the median of all severe convective wind gust proximity soundings, which are 16.1 (Púčik et al., 2015) and about $13.8 \mathrm{~m} \mathrm{~s}^{-1}$ (Taszarek et al., 2017). Compared to proximity soundings in the United States, 0-6 km shear of German warm-seasontype derechos is stronger, with lower and upper quartiles of 15.9 and $24.7 \mathrm{~m} \mathrm{~s}^{-1}$ compared to 11.8 and $20.0 \mathrm{~m} \mathrm{~s}^{-1}$ (Evans and Doswell, 2001). Other parameters (i.e., LFC, low-level mixing ratio) showed less discrimination between derechos and other convective situations in Germany. In conclusion, forecasters need to be aware that warm-season-type derechos can develop in environments with CAPE below $500 \mathrm{~J} \mathrm{~kg}^{-1}$, when concurring strong vertical wind shear and large-scale forcing are present. Strong southwesterly flow at $500 \mathrm{hPa}$ can also indicate derecho potential in such situations.

The remaining 18 of 40 derechos are of the cold-season type. In contrast to the warm-season type, these derechos form in strong northwesterly $500 \mathrm{hPa}$ flow, mostly at the southwestern flank of rapidly amplifying $500 \mathrm{hPa}$ troughs. These troughs are always associated with PV intrusions from upper levels down to $500 \mathrm{hPa}$, and derechos form close to the PV intrusions. Such a weather pattern is typically not associated with frequent thunderstorms across Germany (Piper et al., 2019). Cold-season-type derechos have a clear frequency peak from December to February, but some events occur as early as October or as late as May. Proximity soundings indicate high-shear-low-CAPE environments, and cold-season-type derechos are associated with exceptionally strong $0-1$ and $0-6 \mathrm{~km}$ vertical wind shears with medians of 21 and $35 \mathrm{~m} \mathrm{~s}^{-1}$, respectively. These median shear values are stronger than for cold-season severe convective wind events in central Europe (18 and $33 \mathrm{~m} \mathrm{~s}^{-1}$ Púčik et al., 2015) and cold-season bow echo environments in the continental United States, with a mean $0-2.5 \mathrm{~km}$ shear of $14 \mathrm{~m} \mathrm{~s}^{-1}$ and a mean $0-5 \mathrm{~km}$ shear of $23 \mathrm{~m} \mathrm{~s}^{-1}$, respectively (Burke and Schultz, 2004). Mixed-layer CAPE has a median of $3 \mathrm{~J} \mathrm{~kg}^{-1}$ and is zero in $41 \%$ of cold-season-type derecho proximity soundings. Moreover, the equilibrium level temperature has a median of $-7.5^{\circ} \mathrm{C}$ and frequently does not indicate any potential for thunderstorms close to cold-season-type derechos. Forecast parameters based on CAPE may thus fail to indicate derecho potential in these cases. The limited capability of CAPE-based forecast parameters to provide insight on cold-season convective potential has been discussed in the United States (Sherburn et al., 2016). On the other hand, the relation to mid-tropospheric PV intrusions is promising with respect to forecasting of cold-season-type derechos. Further work should thus focus on PV intrusions and their relation to cold-season-type derechos.

Despite the differences with respect to the large-scale flow and environmental conditions, the comparison of warmseason- and cold-season-type derechos reveals no clear differences in terms of their intensity. On the one hand, a larger fraction of warm-season-type derechos reach moderate or high-end intensity (54\% and $14 \%$, respectively) compared to cold-season-type derechos (39\% and $11 \%$, respectively). On the other hand, the most intense derecho during the investigation period is of the cold-season-type, and cold-seasontype derecho path lengths are about 1.4 times longer on aver- 
age ( $880 \mathrm{~km}$ compared to $620 \mathrm{~km}$ for the warm-season type). The potential impact of cold-season-type derechos in Germany is thus expected to be similar to that of warm-seasontype derechos.

Data availability. NCEP Reanalysis 2 data are provided by the NOAA/OAR/ESRL PSD, Boulder, Colorado, USA, from their website at https://doi.org/10.5065/KVQZ-YJ93 (National Centers for Environmental Prediction/National Weather Service/NOAA/U.S. Department of Commerce, 2000). Radar and wind data are available via the DWD website (https://www.dwd.de/DE/Home/home_ node.html; Schreiber, 1998). The MeteoGroup data are not freely available but can be made available via the provider. All code is available from the authors.

Author contributions. CPG, AHF, DMS, and JGP conceived and designed the research. CPG performed the analysis, prepared the figures, and wrote the initial draft of the paper. All authors contributed with discussions and revisions.

Competing interests. The authors declare that they have no conflict of interest.

Acknowledgements. We thank the NCAR for the provision of reanalysis and GFS data. We thank the DWD for radar and wind data and MeteoGroup for additional wind data and the permission to use the wetter4 display tool. Patrick Ludwig prepared the map presented in Fig. 1a. We are grateful to the European Severe Storms Laboratory (ESSL) for the reports taken from the European Severe Weather Database (ESWD; http://www.eswd.eu/, last access: 18 November 2018).

Financial support. Joaquim G. Pinto was supported by the AXA Research Fund. Partial funding for David M. Schultz was provided to the University of Manchester by the Natural Environment Research Council (grant no. NE/N003918/1).

Review statement. This paper was edited by Piero Lionello and reviewed by Mateusz Taszarek and one anonymous referee.

\section{References}

Apsley, M. L., Mulder, K. J., and Schultz, D. M.: Reexamining the United Kingdom's greatest tornado outbreak: Forecasting the limited extent of tornadoes along a cold front, Weather Forecast., 31, 853-875, https://doi.org/10.1175/waf-d-15-0131.1, 2016.

Ashley, W. S. and Mote, T. L.: Derecho hazards in the United States, B. Am. Meteorol. Soc., 86, 1577-1592, https://doi.org/10.1175/BAMS-86-11-1577, 2005.
Ashley, W. S., Mote, T. L., and Bentley, M. L.: Derecho families, in: Preprints, 22nd Conf. on Severe Local Storms, Hyannis, MA, American Meteorological Society, P4.4, 2004.

BBC: Pukkelpop storm: Belgian festival deaths reach five, available at: https://www.bbc.co.uk/news/world-europe-14586001 (last access: 4 April 2019), 2011.

Bentley, M. L. and Sparks, J. A.: A 15-year climatology of derecho producing mesoscale convective systems over the Central and Eastern United States, Clim. Res., 24, 129-139, https://doi.org/10.3354/cr024129, 2003.

Berkhin, P.: A survey of clustering data mining techniques, in: Grouping multidimensional data, 25-71, Springer, 2006.

Brooks, H. E., Doswell, C. A., and Cooper, J.: On the environments of tornadic and nontornadic mesocyclones, Weather Forecast., 9, 606-618, https://doi.org/10.1175/15200434(1994)009<0606:oteota>2.0.co;2, 1994.

Burke, P. C. and Schultz, D. M.: A 4-yr climatology of cold-season bow echoes over the continental United States, Weather Forecast., 19, 1061-1074, https://doi.org/10.1175/811.1, 2004.

Celiński-Mysław, D. and Matuszko, D.: An analysis of selected cases of derecho in Poland, Atmos. Res., 149, 263-281, https://doi.org/10.1016/j.atmosres.2014.06.016, 2014.

CNN: Cable News Network: French storm tragedy inquiry, available at: http://www.cnn.com/2001/WORLD/europe/07/08/ france.storm.inquiry/index.html (last access: 25 October 2018), 2001.

Coniglio, M. C. and Stensrud, D. J.: Interpreting the climatology of derechos, Weather Forecast., 19, 595-605, https://doi.org/10.1175/1520 0434(2004)019<0595:itcod>2.0.co;2, 2004.

Coniglio, M. C., Stensrud, D. J., and Richman, M. B.: An observational study of derecho-producing convective systems, Weather Forecast., 19, 320-337, https://doi.org/10.1175/15200434(2004)019<0320:aosodc>2.0.co;2, 2004.

Corfidi, S. F.: Cold pools and MCS propagation: Forecasting the motion of downwind-developing MCSs, Weather Forecast., 18, 997-1017, https://doi.org/10.1175/15200434(2003)018<0997:cpampf>2.0.co;2, 2003.

Die Welt: Sturm in NRW kostet die Bahn 60 Millionen Euro, available at: https://www.welt.de/wirtschaft/article129217572/ Sturm-in-NRW-kostet-die-Bahn-60-Millionen-Euro.html (last access: 12 July 2019), 2014.

Doswell, C. A.: Severe convective storms - An overview, in: Severe convective storms, 1-26, Springer, 2001.

Doswell, C. A. and Rasmussen, E. N.: The effect of neglecting the virtual temperature correction on CAPE calculations, Weather Forecast, 9, 625-629, 1994.

Dotzek, N., Groenemeijer, P., Feuerstein, B., and Holzer, A. M.: Overview of ESSL's severe convective storms research using the European Severe Weather Database ESWD, Atmos. Res, 93, 575-586, https://doi.org/10.1016/j.atmosres.2008.10.020, 2009.

DWD: AKORD-Anwenderkoordinierte Organisation von RadarDaten, Produktkatalog, DWD-Geschäftsfeld Hydrometeorologie, Selbstverlag, 1997.

Evans, J. S. and Doswell, C. A.: Examination of derecho environments using proximity soundings, Weather Forecast., 16, 329-342, https://doi.org/10.1175/15200434(2001)016<0329:eodeup>2.0.co;2, 2001. 
Evans, M.: An examination of low CAPE/high shear severe convective events in the Binghamton, New York county warning area, National Weather Digest, 34, 129-144, 2010.

Faust, H.: Untersuchungen von Forstschäden hinsichtlich der Windstruktur bei einer Böe, Meteorol. Rundsch., 1, 290-297, 1948.

Fujita, T. T.: Manual of downburst identification for Project Nimrod. Satellite and Mesometeorology Research Paper No. 156, 104 pp., Department of Geophysical Sciences, University of Chicago, Chicago, IL 60637, 1978.

Gatzen, C.: A derecho in Europe: Berlin, 10 July 2002, Weather Forecast., 19, 639-645, https://doi.org/10.1175/15200434(2004)019<0639:adiebj>2.0.co;2, 2004.

Gatzen, C.: A 10-year climatology of cold-season narrow coldfrontal rainbands in Germany, Atmos. Res., 100, 366-370, https://doi.org/10.1016/j.atmosres.2010.09.018, 2011.

Gatzen, C.: Warm-season severe wind events in Germany, Atmos. Res., 123, 197-205, https://doi.org/10.1016/j.atmosres.2012.07.017, 2013.

Gatzen, C., Púčik, T., and Ryva, D.: Two cold-season derechoes in Europe, Atmos. Res., 100, 740-748, https://doi.org/10.1016/j.atmosres.2010.11.015, 2011.

Gospodinov, I., Dimitrova, T., Bocheva, L., Simeonov, P., and Dimitrov, R.: Derecho-like event in Bulgaria on 20 July 2011, Atmos. Res., 158, 254-273, https://doi.org/10.1016/j.atmosres.2014.05.009, 2015.

Groenemeijer, P., Púčik, T., Holzer, A. M., Antonescu, B., RiemannCampe, K., Schultz, D. M., Kühne, T., Feuerstein, B., Brooks, H. E., Doswell, C. A., Koppert, H., and Sausen, R.: Severe convective storms in Europe: Ten years of research and education at the European Severe Storms Laboratory, B. Am. Meteorol. Soc., 98, 2641-2651, https://doi.org/10.1175/BAMS-D-16-0067.1, 2017.

Haase-Straub, S. P., Hagen, M., Hauf, T., Heimann, D., Peristeri, M., and Smith, R. K.: The squall line of 21 July 1992 in southern Germany: An observational case study, Beiträge zur Physik der Atmosphäre-Contributions to Atmospheric Physics, 70, 147166, 1997.

Hamid, K.: Investigation of the passage of a derecho in Belgium, Atmos. Res., 107, 86-105, https://doi.org/10.1016/j.atmosres.2011.12.013, 2012.

Hinrichs, G.: Tornadoes and derechos, American Meteorological Journal, 5, 306-317, 341-349, 1888.

Johns, R. H.: A synoptic climatology of northwest flow severe weather outbreaks. Part I: Nature and significance, Mon. Weather Rev., 110, 1653-1663, https://doi.org/10.1175/15200493(1982)110<1653:asconf>2.0.co;2, 1982.

Johns, R. H.: A synoptic climatology of northwestflow severe weather outbreaks. Part II: Meteorological parameters and synoptic patterns, Mon. Weather Rev., 112, 449-464, https://doi.org/10.1175/15200493(1984)112<0449:asconf>2.0.co;2, 1984.

Johns, R. H.: Meteorological conditions associated with bow echo development in convective storms, Weather Forecast., 8, 294-299, https://doi.org/10.1175/15200434(1993)008<0294:mcawbe>2.0.co;2, 1993.

Johns, R. H. and Hirt, W. D.: Derechos: Widespread convectively induced windstorms, Weather Forecast., 2, 32-49, https://doi.org/10.1175/15200434(1987)002<0032:dwciw>2.0.co;2, 1987.
Kalnay, E., Kanamitsu, M., Kistler, R., Collins, W., Deaven, D., Gandin, L., Iredell, M., Saha, S., White, G., Woollen, J., Zhu, Y., Chelliah, M., Ebisuzaki, W., Higgins, W., Janowiak, J., Mo, K. C., Ropelewski, C., Wang, J., Leetmaa, A., Reynolds, R., Jenne, R., and Joseph, D.: The NCEP/NCAR 40-year reanalysis project, B. Am. Meteorol. Soc., 77, 437-470, https://doi.org/10.1175/15200477(1996)077<0437:TNYRP>2.0.CO;2, 1996.

Kaltenböck, R.: The outbreak of severe storms along convergence lines northeast of the Alps. Case study of the 3 August 2001 mesoscale convective system with a pronounced bow echo, Atmos. Res., 70, 55-75, https://doi.org/10.1016/j.atmosres.2003.11.003, 2004.

King, J. R. and Parker, M. D.: Synoptic influence on high shear, low CAPE convective events., in: Preprints, 27th Conference on Severe Local Storms, Madison, WI, 2014.

Klimowski, B. A., Bunkers, M. J., Hjelmfelt, M. R., and Covert, J. N.: Severe convective windstorms over the northern high plains of the United States, Weather Forecast., 18, 502-519, https://doi.org/10.1175/15200434(2003)18<502:scwotn>2.0.co;2, 2003.

Köppen, W.: Der Gewittersturm vom 9. August 1881 (The thunderstorm squall of 9 August 1881), Annalen der Hydrogeographie und Maritimen Meteorologie, 10, 595-619, 714-737, 1882.

Köppen, W.: Die Windhose vom 5. Juli 1890 bei Oldenburg und die Gewitterböe vom 10. Juli 1896 in Ostholstein (The tornado on 5 July 1890 near Oldenburg and the thundersquall of 10 July 1896 in east Holstein), Annalen der Hydrogeographie und Maritimen Meteorologie, 24, 445-458, 493-508, 546-556, 1896.

Kurz, M.: Severe thunderstorms over western Germany: a casestudy of the weather situation on 20 August 1992, Meteorol. Mag., 122, 177-188, 1993.

Lee, A.: An experimental study of the remote location of lightning flashes using a VLF arrival time difference technique, Q. J. Roy. Meteorol. Soc., 112, 203-229, https://doi.org/10.1002/qj.49711247112, 1986.

López, J. M.: A Mediterranean derecho: Catalonia (Spain), 17th August 2003, Atmos. Res., 83, 272-283, https://doi.org/10.1016/j.atmosres.2005.08.008, 2007.

Mahoney, K. M., Lackmann, G. M., and Parker, M. D.: The role of momentum transport in the motion of a quasi-idealized mesoscale convective system, Mon. Weather Rev., 137, 33163338, https://doi.org/10.1175/2009mwr2895.1, 2009.

Markowski, P. M., Straka, J. M., Rasmussen, E. N., and Blanchard, D. O.: Variability of stormrelative helicity during VORTEX, Mon. Weather Rev., 126, 2959-2971, https://doi.org/10.1175/15200493(1998)126<2959:vosrhd>2.0.co;2, 1998.

Mathias, L., Ermert, V., Kelemen, F. D., Ludwig, P., and Pinto, J. G.: Synoptic Analysis and Hindcast of an Intense Bow Echo in Western Europe: The 9 June 2014 Storm, Weather Forecast., 32, 1121-1141, https://doi.org/10.1175/waf-d-16-0192.1, 2017.

Mathias, L., Ludwig, P., and Pinto, J. G.: Synoptic-scale conditions and convection-resolving hindcast experiments of a cold-season derecho on 3 January 2014 in western Europe, Nat. Hazards Earth Syst. Sci., 19, 1023-1040, https://doi.org/10.5194/nhess19-1023-2019, 2019. 
Müllner, D.: Modern hierarchical, agglomerative clustering algorithms, arXiv:1109.2378, http://arxiv.org/abs/1109.2378 (last access: 20 March 2018), 2011.

National Centers for Environmental Prediction/National Weather Service/NOAA/U.S. Department of Commerce: NCEP/DOE Reanalysis 2 (R2), Research Data Archive at the National Center for Atmospheric Research, Computational and Information Systems Laboratory, https://doi.org/10.5065/KVQZ-YJ93, 2000.

Piper, D. A., Kunz, M., Allen, J. T., and Mohr, S.: Investigation of the temporal variability of thunderstorms in Central and Western Europe and the relation to large-scale flow and teleconnection patterns, Q. J. Roy. Meteorol. Soc., 145, 3644-3666, https://doi.org/10.1002/qj.3647, 2019.

Pistotnik, G., Holzer, A. M., Kaltenböck, R., and Tschannett, S.: An F3 downburst in Austria - A case study with special focus on the importance of real-time site surveys, Atmos. Res., 100, 565-579, https://doi.org/10.1016/j.atmosres.2010.10.011, 2011.

Potvin, C. K., Elmore, K. L., and Weiss, S. J.: Assessing the impacts of proximity sounding criteria on the climatology of significant tornado environments, Weather Forecast., 25, 921-930, https://doi.org/10.1175/2010waf2222368.1, 2010.

Przybylinski, R. W.: The bow echo: Observations, numerical simulations, and severe weather detection methods, Weather Forecast., 10, 203-218, https://doi.org/10.1175/15200434(1995)010<0203:tbeons >2.0.co;2, 1995.

Púčik, T., Francová, M., Rva, D., Kolář, M., and Ronge, L.: Forecasting challenges during the severe weather outbreak in Central Europe on 25 June 2008, Atmos. Res., 100, 680-704, https://doi.org/10.1016/j.atmosres.2010.11.014, 2011.

Púčik, T., Groenemeijer, P., Rva, D., and Kolář, M.: Proximity Soundings of Severe and Nonsevere Thunderstorms in Central Europe, Mon. Weather Rev., 143, 4805-4821, https://doi.org/10.1175/mwr-d-15-0104.1, 2015.

Punkka, A.-J., Teittinen, J., and Johns, R. H.: Synoptic and mesoscale analysis of a high-latitude derecho-severe thunderstorm outbreak in Finland on 5 July 2002, Weather Forecast., 21, 752-763, https://doi.org/10.1175/waf953.1, 2006.

Rädler, A. T., Groenemeijer, P., Faust, E., and Sausen, R.: Detecting severe weather trends using an additive regressive convective hazard model (AR-CHaMo), J. Applied Meteorol. Climatol., 57, 569-587, https://doi.org/10.1175/JAMC-D-17-0132.1, 2018.

Rotunno, R., Klemp, J. B., and Weisman, M. L.: A theory for strong, long-lived squall lines, J. Atmos. Sci., 45, 463-485, https://doi.org/10.1175/15200469(1988)045<0463:atfsll>2.0.co;2, 1988.

Schreiber, K. J.: Der Radarverbund des Deutschen Wetterdienstes. Annalen der Meteorologie, 38, Herbstschule Radarmeteorologie, available at: https://www.dwd.de/DE/leistungen/pbfb_verlag_ annalen/pdf_einzelbaende/38_pdf.pdf?_blob=publicationFile\& v=3 (last access: 7 May 2020), 1998.
Sherburn, K. D. and Parker, M. D.: Climatology and ingredients of significant severe convection in high-shear, low-CAPE environments, Weather Forecast., 29, 854-877, https://doi.org/10.1175/waf-d-13-00041.1, 2014.

Sherburn, K. D., Parker, M. D., King, J. R., and Lackmann, G. M.: Composite Environments of Severe and Nonsevere High-Shear, Low-CAPE Convective Events, Weather Forecast., 31, 18991927, 2016.

Siedlecki, M.: Selected instability indices in Europe, Theor. Appl. Climatol., 96, 85-94, https://doi.org/10.1007/s00704-008-00344, 2009

Siemens: Blids, available at: https:/www.industry.siemens.com/ services/global/de/portfolio/plant-data-services/blids/seiten/ default.aspx (last access: 4 April 2019), 2019 (in German).

Simon, A., Kaňák, J., Sokol, A., Putsay, M., Uhrínová, L., Csirmaz, K., Okon, L., and Habrovsk, R.: Case study of a severe windstorm over Slovakia and Hungary on 25 June 2008, Atmos. Res., 100, 705-739, https://doi.org/10.1016/j.atmosres.2010.12.012, 2011.

Smull, B. F. and Houze, R. A.: Rear inflow in squall lines with trailing stratiform precipitation, Mon. Weather Rev., 115, 2869-2889, https://doi.org/10.1175/15200493(1987)115<2869:riislw>2.0.co;2, 1987.

Taszarek, M., Brooks, H. E., and Czernecki, B.: Sounding-derived parameters associated with convective hazards in Europe, Mon Weather Rev., 145, 1511-1528, 2017.

Taszarek, M., Pilguj, N., Orlikowski, J., Surowiecki, A., Walczakiewicz, S., Pilorz, W., Piasecki, K., Pajurek, Ł., and Półrolniczak, M.: Derecho Evolving from a Mesocyclone - A Study of 11 August 2017 Severe Weather Outbreak in Poland: Event Analysis and High-Resolution Simulation, Mon. Weather Rev., 147, 2283-2306, https://doi.org/10.1175/MWR-D-18-0330.1, 2019.

Toll, V., Männik, A., Luhamaa, A., and Rõõm, R.: Hindcast experiments of the derecho in Estonia on 08 August, 2010: Modelling derecho with NWP model HARMONIE, Atmos. Res., 158, 179_ 191, https://doi.org/10.1016/j.atmosres.2014.10.011, 2015.

van den Broeke, M. S., Schultz, D. M., Johns, R. H., Evans, J. S., and Hales, J. E.: Cloud-to-ground lightning production in strongly forced, low-instability convective lines associated with damaging wind, Weather Forecast., 20, 517-530, https://doi.org/10.1175/waf876.1, 2005.

Wapler, K.: High-resolution climatology of lightning characteristics within Central Europe, Meteorol. Atmos. Phys., 122, 175-184, https://doi.org/10.1007/s00703-013-0285-1, 2013.

wetterzentrale.de: Lightning archive of Wetterzentrale, available at: http://old.wetterzentrale.de/topkarten/fsbeobl.html, last access: 1 September 2016. 